\title{
EL SISTEMA ELECTORAL ESPAÑOL DESDE SUS ORÍGENES HASTA LA CONSTITUCIÓN DE $1978^{1}$
}

\section{THE SPANISH ELECTORAL SYSTEM FROM ITS ORIGINS TO THE CONSTITUTION OF 1978}

\author{
Miguel Ángel Presno Linera \\ Universidad de Oviedo
}

\begin{abstract}
SUMARIO: I. LAS ELECCIONES EN LA HISTORIA CONSTITUCIONAL ESPAÑOLA DESDE 1810 HASTA 1936. 1.1. El nacimiento del derecho electoral español: 1810-1820. 1.2. La consolidación del derecho electoral: 1834-1868. 1.3. La revolución del sufragio universal masculino y sus vaivenes posteriores: 18681931. 1.4. La plena democratización del sufragio: 1931-1936. II. PREDOMINIO DE LOS SISTEMAS ELECTORALES MAYORITARIOS EN LA HISTORIA CONSTITUCIONAL ESPAÑOLA. III.- EL SISTEMA ELECTORAL A PARTIR DE LA TRANSICIÓN Y DE LA CONSTITUCIÓN DE 1978. 3.1. El derecho electoral de la Transición. 3.2. La opción por un sistema electoral supuestamente proporcional. 3.3. Un sistema electoral de listas cerradas y bloqueadas para el Congreso y de lista abierta para el Senado. 3.4. Un sistema electoral proporcional que produce resultados desiguales. IV.- EPÍLOGO: ¿EL SISTEMA ELECTORAL EN EL FUTURO?
\end{abstract}

Resumen: En este texto se analiza la evolución del derecho electoral español, desde sus orígenes en el año 1810, hasta la actualidad, con especial énfasis en su regulación en normas constitucionales -desde la Constitución de 1812 a la de 1978, pero también en normas legales y reglamentarias.

Abstract: In this paper we analyze the evolution of the Spanish Electoral Law, from its origins in the year 1810, until the present day, with special emphasis on its regulation in constitutional norms -from the Constitution of 1812 to the Constitution of 1978-, but also in legal and regulatory procedures.

Palabras clave: historia constitucional, derecho electoral, sistema electoral, elecciones.

Key Words: Constitutional History, Electoral Law, Electoral System, Elections.

\footnotetext{
1. En este texto se incluyen aportaciones realizadas en trabajos anteriores; principalmente, " $E l$ origen del derecho electoral español", Revista Española de Derecho Constitucional, n ${ }^{\circ}$ 96, 2012, pp. 163.186; Leyes y normas electorales en la historia constitucional española, Iustel, 2013; "Cuarenta años del sistema electoral español", La Constitución Española: 1978-2018, coordinado por María Isabel Álvarez Vélez y Carlos Vidal Prado, Manual Francis Lefrebvre, Madrid, 2018, pp. 149-162
} 


\section{LAS ELECCIONES EN LA HISTORIA CONSTITUCIONAL ESPAÑOLA DESDE 1810 HASTA 1936.}

A la pregunta sobre el contenido que debe tener una norma para que merezca el calificativo de electoral se pueden dar diferentes respuestas, pero, en general, se conviene en incluir el núcleo jurídico central relativo al conjunto de actos que integran el proceso electoral, materia en la que se comprende qué personas pueden elegir y cómo pueden hacerlo, a quiénes pueden elegir y bajo qué condiciones, para qué espacio de tiempo y con qué criterios organizativos desde el punto de vista procedimental y territorial.

En la historia constitucional española ese contenido mínimo ha estado regulado en normas de rangos bien diferentes, desde la Constitución a los reglamentos, pasando por un buen número de leyes electorales. A continuación, y con el mero propósito de ofrecer una perspectiva panorámica, se expondrán de manera sucinta los hitos esenciales de cada una de las etapas en las que podría dividirse ese recorrido centenario ${ }^{2}$.

\subsection{El nacimiento del derecho electoral español: 1810-1820.}

La primera norma que, con justicia, puede calificarse de electoral es la Instrucción que deberá observarse para la elección de Diputados de Cortes, de 1 de enero de $1810^{3}$, a la que pronto siguió el Decreto de 29 de enero por el que se convocaron Cortes generales y extraordinarias de representantes de toda la nación española 4 . Como normas complementarias se aprobaron otra Instrucción Adicional de 9 de septiembre y sendos decretos de 14 de febrero sobre las provincias de Ultramar5, y 8 de septiembre sobre el número de Diputados

\footnotetext{
2. Francesc De Carreras y Josep M. Vallés analizan el derecho electoral español entre 1808 y 1977 en su libro Las elecciones. Apéndice: Ley para la Reforma Politica y Ley Electoral comentada, Editorial Blume, Barcelona, 1977, pp. 203 ss.

3. Leyes electorales y proyectos de ley, Imprenta Hijos de J. A. Garcia, Madrid, 1906, pp. 19 ss.; disponible también en http://www.ih.csic.es/paginas/jrug/elecciones/index_ley.htm Sobre las escasas previsiones incluidas en el Estatuto de Bayona, véase el comentario introductorio de Ignacio Fernández Sarasola a La Constitución de Bayona, número I de la colección, dirigida por el profesor Miguel Artola, Las Constituciones españolas, Iustel, Madrid, 2007, pp. 73 ss.

4. Colección de Leyes Fundamentales, textos editados por Ramón Sáinz de Varanda, Acribia, Zaragoza, 1957, pp. 21 a 25; disponible también en el portal temático de la Constitución española de 1812, coordinado por Ignacio Fernández Sarasola para la Biblioteca Virtual Miguel de Cervantes:
}

http://www.cervantesvirtual.com/portal/1812/juntista.shtml

Sobre las diferentes posturas que se manifestaron en 1809 sobre cómo debían convocarse las Cortes y cuáles debian ser sus poderes, véase el trabajo de Joaquín Varela Suanzes, "Las Cortes de Cádiz y la Constitución de 1812", en el libro del mismo autor Tres ensayos sobre historia constitucional, Universidad Inca Garcilaso de la Vega/Instituto Iberoamericano de Derecho Constitucional, Lima, 2008, pp. 81 ss.; en este estudio también se comenta la extraña desaparición del mencionado Decreto (p. 83).

5. Leyes electorales y proyectos de ley, Imprenta Hijos de J. A. Garcia, Madrid, 1906, pp. 47 a 55 . 
suplentes de las dos Américas y de las provincias ocupadas por el enemigo, y dictando reglas para esta elección ${ }^{6}$.

Sobre el contenido de estas normas nos ocuparemos de inmediato, pero debe resaltarse que encontramos en el momento fundacional del derecho electoral español la presencia de normas reglamentarias, lo que será una constante del sistema hasta 1977.

En la Instrucción de 1810 aparecen ya los modos de elegir a los diferentes representantes (parroquiales, de partido y provinciales), el mapa electoral con la distribución de diputados por circunscripciones, la composición y funciones de la Junta encargada de hacer cumplir la instrucción y de presidir las elecciones de Diputados en las capitales de provincia, los requisitos para votar y para ser elegido, y la fórmula electoral (mayoritaria) a aplicar en cada elección. El sufragio es, en apariencia, universal masculino e indirecto. Decimos que es en apariencia universal pues se requería "tener casa abierta", exigencia alusiva a la necesidad de que los electores ejerciesen algún tipo de industria. Se elegía un Procurador o Diputado de Cortes "por cada 50.000 almas que tenga aquella provincia con arreglo al último censo español publicado en el año de 1797"7.

Además de la función que cumplió como primera disposición electoral, la Instrucción sirvió como fuente de inspiración para el siguiente hito normativo en la materia, que tuvo nada menos que rango constitucional, pues la Constitución de 1812 reguló con extraordinaria minuciosidad todo el proceso electoral ${ }^{8}$, al que dedica los artículos 27 a 103, convirtiéndose en una auténtica norma electoral, cosa que no volverá a ocurrir en los textos fundamentales posteriores ${ }^{9}$. Hasta tal punto es así que la Constitución, además de establecer un sistema de representación nacional (art. 27), prevé una regulación más exhaustiva que la incluida en la Instrucción de 1810, incluyendo "el modo de formarse las Cortes", donde se prevé que habrá 1 diputado "por cada 70.000 almas", junto con la forma en la que se procederá al nombramiento de Diputados de Cortes a partir de las elecciones en la parroquia, el partido y la provincia, introduciendo, junto a los requisitos exigidos para ser elector y candidato, por vez primera, supuestos de inelegibilidad.

El sufragio fue universal masculino e indirecto "para los ciudadanos", aunque la Constitución incluyó dos exigencias que no llegaron aplicarse: una capacitaria para el sufragio activo (desde 1830 debian saber leer y escribir, art. 25.6) y una censitaria para el pasivo (los candidatos a las Juntas de Provincia debían poseer una renta anual proporcionada procedente de bienes propios, art. 92, lo que se aplicaría cuando las Cortes "que en adelante han de celebrarse 75.

6. Leyes electorales y proyectos de ley, Imprenta Hijos de J. A. Garcia, Madrid, 1906, pp. 63 a

7. Sobre esta Instrucción, véase el comentario de Eugenio Ull Pont, "Orígenes del derecho electoral español", Boletín Informativo del Departamento de Derecho Político de la UNED, $\mathrm{n}^{\circ}$ 2, pp. 38 ss.

8. Sobre la Constitución de Cádiz es de extraordinaria utilidad la página que dirige Ignacio Fernández Sarosola y coordina Fernando Reviriego Picón en la Biblioteca Virtual Miguel de Cervantes: http://www.cervantesvirtual.com/FichaAutor.html?Ref=4149\&portal=56.

9. Una obra clásica sobre las Constituciones españolas hasta 1931, en la que también se presta atención a los diferentes cambios en el sistema electoral, es la del Luis Sánchez Agesta, Historia del constitucionalismo español, Instituto de Estudios Políticos, Madrid, 1955; 4ª edición, 1984. 
declaren haber llegado ya el tiempo de que pueda tener efecto", art. 93). Por vez primera, el voto es secreto, pero únicamente en las elecciones de las Juntas electorales de partido.

Sobre la titularidad del sufragio ${ }^{10}$ debe apuntarse que no resultó ajeno al texto de 1812 lo previsto 21 años antes en la Constitución francesa de 1791 y que en nuestro país desembocó en la diferencia entre "españoles", titulares de derechos civiles como la libertad y la propiedad, y "ciudadanos", que, además, podian elegir y ser elegidos. A esta distinción se aludia en el Discurso Preliminar a la Constitución al exigir que "la libertad civil de los españoles quede no menos afianzada en la ley fundamental del Estado que lo está ya la libertad política de los ciudadanos"11.

Las previsiones constitucionales tuvieron su complemento en el Real Decreto del Ministerio de Gobernación de la Península de convocatoria a Cortes e instrucciones para la elección de los diputados, de 22 de marzo de $1820^{12}$, donde se reguló con detalle la elección de diputados "en la Península e Islas Adyacentes", otorgando un papel importante en la organización de las mismas al Jefe superior de cada provincia, que formará, a tal efecto, una "Junta preparatoria"13. El número de diputados a elegir era de 149 (1 por cada "70.000 almas"), con 54 suplentes, que tenían derecho a "ciento diez reales vellón diarios por razón de dietas, que abonarán las respectivas provincias" (art. 11).

\subsection{La consolidación del derecho electoral: 1834-1868.}

Nada tuvo que ver lo dispuesto en la Constitución de 1812 con el previsto por el Estatuto Real para la convocación de la Cortes Generales del Reino, de 1834, donde además de desaparecer "la representación única de la Nación" se redujo al mínimo el contenido electoral, dividiéndose las Cortes en el Estamento de Próceres del Reino (art. 3 y siguientes), compuesto por miembros natos y otros elegidos por el Rey, y el de Procuradores del Reino, de elección con arreglo a la ley (art. 13 y siguientes) ${ }^{14}$.

10. Sobre la cuestión del sufragio, véanse los estudios de Pierre Rosanvallo, La sacre du citoyen. Histoire du suffrage universel en France, Gallimard, París, 1992, y, centrado en la Revolución francesa, Michel Troper, "La notion de citoyen sous la Révolution française", Etudes en l'honneur du George Dupuis, LGDJ, 1997; sobre la articulación de la nacionalidad y ciudadanía como círculos concéntricos en la Francia revolucionaria y la España gaditana, Benito Aláez Corral, Nacionalidad, ciudadanía y democracia. ¿A quién pertenece la Constitución?, CEPC, Madrid, 2006, pp. 50 ss.

11. Véase sobre esta cuestión y el debate al respecto en la Cortes de Cádiz el trabajo de Joaquín Varela Suanzes, "Propiedad y sufragio en el constitucionalismo español (1810-1845)", en el libro colectivo coordinado por ese autor Propiedad e historia del derecho, Fundación Beneficentia et peritia iuris, Madrid, 2005, pp. 49 ss.

12. Colección de Decretos y Órdenes generales expedidos por las Cortes ordinarias de los años de 1820 y 1821 en el segundo periodo de su Diputación que comprende desde 25 de febrero hasta 30 de junio del último año, Imprenta Nacional, Madrid, 1821, pp. 45 ss.

13. Se componía, junto al Jefe superior, del "arzobispo u obispo, o en su defecto del eclesiástico mas condecorado del pueblo donde se celebrare la junta, del intendente donde le hubiere, del alcalde mas antiguo del regidor decano y del sindico procurador general de la capital de la provincia, y de dos hombres buenos vecinos de la misma provincia, y nombrados por las personas arriba mencionadas" (art. 2).

14. Véase la edición de El Estatuto Real y de la Constitución de 1837 a cargo de Juan Pro Ruíz, volumen III de la colección Las Constituciones españolas, Iustel, Madrid, 2008. 
La desnudez del Estatuto permitirá que existan diferentes formas de vestir legalmente el derecho electoral, posibilidad que no desaparecerá con las Constituciones de 1837 y 1845, que, como ha señalado Fernández Sarasola15, representan una puerta abierta a las divisiones ideológicas dentro del sistema. Dicha alternativa se evidenciará con las sucesivas leyes electorales de la época, que, en palabras de Balmes, "son susceptibles de arreglarse sobre infinita variedad de bases sin tocar en lo más mínimo a la Constitución"16.

En realidad, las normas por las que se regirán las siguientes elecciones de Procuradores no tendrán forma legal sino que seguirán siendo de indole reglamentaria ${ }^{17}$ : los decretos de 20 de mayo de 1834 de convocatoria de Cortes ${ }^{18}$ y para la elección de procuradores a las Cortes del Reino ${ }^{19}$ y el decreto de 24 de mayo de $1836^{20}$.

El Decreto para la elección de procuradores, de 1834, articuló un sistema de elección indirecta de dos grados: Juntas electorales de partido que elegían a los electores de las Juntas de provincia, que a su vez designarian a los procuradores de la circunscripción; la Junta de partido incluía a "todos los individuos de que a la sazón conste el Ayuntamiento del pueblo cabeza de partido, incluso los Síndicos y Diputados" más "un número de mayores contribuyentes del pueblo cabeza de partido, igual al de los individuos del Ayuntamiento" (art. 3). Estas exigencias redujeron el cuerpo electoral a poco más de 16.000 personas $^{21}$, un infimo porcentaje de la población.

El Decreto de 1836 fue más extenso que el de 1834 y, desde una óptica contemporánea, supuso la primera norma "moderna" de la historia electoral española: reguló el número de diputados, las exigencias del sufragio activo y pasivo, la formación de las listas del censo, con la posibilidad de presentar reclamaciones, el modo de ejercer el voto, incluso a través de la ayuda de otro elector, qué votos debían considerarse nulos, el escrutinio y la formalización de actas electorales, las potestades de los presidentes de las Juntas, habló ya de “mesas", "papeletas", "urna electoral”,... Con estas previsiones, el censo electoral

15. Los partidos políticos en el pensamiento español. De la Ilustración a nuestros dias, Marcial Pons, Madrid, 2009. p. 91

16. Jaime Balmes, “Consideraciones politicas sobre la situación de España", en Politica y Constitución, edición de Joaquín Varela Suanzes, CEC, Madrid, 1988, pp. 53 y 54.

17. Son referencia obligada para el estudio de este período los libros de Fermín Caballero, El Gobierno y las Cortes del Estatuto: materiales para su historia, Imprenta de Yenes, Madrid, 1837; Antonio Alcalá Galiano, Historia de España desde los tiempos primitivos hasta la mayoria de edad de la Reina doña Isabel II, T. VII, Imprenta de la Sociedad Literaria y Tipográfica, Madrid, 1846, y, ya en el siglo XX, Joaquín Tomás Villaroya, El sistema político del Estatuto Real (1834-1836), Instituto de Estudios Políticos, Madrid, 1968; sobre la estructura política del período, el trabajo de Isabel Burdiel, La politica de los notables. Moderados y avanzados durante el régimen del Estatuto Real, 1834-1836, Alfons el Magnànim, Valencia, 1987.

18. Gaceta de Madrid, de 24 de mayo de 1834.

19. Gaceta de Madrid, de 25 de mayo de 1834.

20. Gaceta de Madrid, de 26 de mayo de 1836.

21. Así lo sostiene Fermín Caballero, Reseña de las últimas elecciones para Diputados y Senadores, Madrid, 1837, p. 16. 
se empezó a articular como tal ${ }^{22}$ y se extendió a 65.067 personas, el 0,50\% de la población $^{23}$, disponiéndose la elección de un diputado por cada 50.000 personas. Entre las provincias peninsulares, las Islas Adyacentes (Baleares y Canarias) y las Islas de Ultramar se elegian 258 diputados.

Desde el Decreto de 1834 el sufragio pasó a ser censitario y capacitario, y desde el Decreto de 1836 se convirtió en directo ${ }^{24}$.

Ese contenido se reproducirá, esencialmente, en las Leyes de 20 de julio de $1937^{25}$ y de 18 de marzo de $1846^{26}$, si bien se pueden encontrar en ambas normas rasgos distintivos ${ }^{27}$, respectivamente, del liberalismo progresista en el primera y del moderado en la segunda ${ }^{28}$, que en materia electoral se ejemplifican en la mayor o menor ampliación del censo y en el decantamiento a favor de la provincia o el distrito uninominal como circunscripción electoral.

Previamente, la Constitución de 1837 reguló de manera sucinta las condiciones para la elección de los senadores (arts. 14 a 20) y diputados (arts. 21 a 25), añadiendo que cada provincia "nombrará un Diputado, a lo menos, por cada cincuenta mil almas de su población" y que "los Diputados serán elegidos por tres años"29, previsiones objeto de "moderación" con la Constitución de 1845, que potenció el papel de la Cámara Alta ${ }^{30}$.

22. Véase el estudio de Artemi Rallo Lombarte, "Creación del censo electoral y primeros intentos de judicialización de las garantias electorales en España (1834-1877)", Cuadernos constitucionales de la Cátedra Fadrique Furió Ceriol, n 9-10, 1995 (Ejemplar dedicado a Estudios de Historia, politica y derecho en homenaje a Joaquín Tomás Villarroya), pp. 225 ss.

23. Joaquín Tomás Villaroya, Historia de España. La Era Isabelina y el sexenio democrático (1834-1878), vol. XXXIV de la Historia de España, de Ramón Menéndez Pidal, p. 36.

24. Sobre la relación entre voto y propiedad en la historia constitucional española durante la primera mitad del siglo XIX véase el estudio, ya citado, de Joaquín Varela Suanzes, "Propiedad y sufragio en el constitucionalismo español (1808-1845)", Propiedad e historia del derecho.

25. Gaceta de Madrid, de 22 de julio de 1837; sobre esta Ley, véase Joaquín Tomás Villaroya, "El cuerpo electoral en la Ley de 1837", Revista del Instituto de Ciencias Sociales, Diputación de Barcelona, 1964, pp. 157 ss.

26. Gaceta de Madrid, de 21 de marzo de 1846.

27. Véase el estudio de María Sierra "Electores y ciudadanos en los proyectos politicos del liberalismo moderado y progresista", en De súbditos a ciudadanos. Una historia de la ciudadanía en España, estudio dirigido por Manuel Pérez Ledesma, CEPC, Madrid, 2007 pp. 103 ss.; no comparte esta visión diferenciadora entre moderados y progresistas en lo atinente a la normativa electoral Manuel Estrada Sánchez, El significado politico de la legislación electoral en la España de Isabel II, Universidad de Cantabria, Santander, 1999.

28. Sobre el sufragio como función política vinculada a la capacidad de la persona véanse los estudios de Luis Díez del Corral, El liberalismo doctrinario, Instituto de Estudios Políticos, Madrid, 1973, y Ángel Garrorena Morales, EL Ateneo de Madrid y la teoría de la Monarquía Liberal, 18361847, Instituto de Estudios Políticos, Madrid, 1974.

29. Véase al respecto el libro de Antonio Colomer Viadel, El sistema político de la Constitución española de 1837, Congreso de los Diputados, Madrid, 1989, así como el estudio de Joaquín Varela Suanzes, "La Constitución española de 1837: una Constitución transaccional", Revista de Derecho Político de la UNED, $\mathrm{n}^{\circ}$ 20, pp. 95 ss.; recopilado en el libro Política y Constitución en España (1808-1978), CEPC, Madrid, 2007, pp. 311 ss.

30. Sobre esta Constitución véase la edición de Juan Ignacio Marcuello Benedicto, La Constitución de 1845, volumen IV de la colección Las Constituciones españolas, Iustel, Madrid, 2007. 
Bajo la Ley de 1837 se realizaron 7 elecciones en las que el sufragio fue censitario y capacitario, el número de diputados "propietarios" era de 241 y el de suplentes 134, la relación diputado por habitante de 1 por cada 50.000 y la fórmula electoral mayoritaria. Esta Ley aportó la novedad de los diputados suplentes, que (art. 5) "serían llamados solamente a ejercer su encargo cuando algún Diputado propietario nombrado en la misma elección sea elegido Senador o cuando por cualquiera causa no llegue a tomar asiento en el Congreso" 31 . Y debe destacarse que en su discusión parlamentaria se llegó a proponer la rebaja de la edad electoral a los 18 años, pretensión que no prosperó al considerarse que aunque "en los países meridionales [los hombres] se desarrollan algo antes [de los 25 años], también es cierto que en los países septentrionales aún a esa edad no están completamente desarrollados" (intervención del diputado González Alonso rebatiendo la del diputado Charco favorable a los 18 años) ${ }^{32}$.

Se ha señalado que en esta norma tuvo una clara influencia la reforma electoral inglesa de 1832, especialmente en la atribución del sufragio a los arrendatarios rurales de cierto nivel de renta y a los inquilinos urbanos ${ }^{33}$.

Con la Ley de 18 de marzo de 1846 desaparecieron los diputados suplentes y se previó que (art. 1) "el Congreso de los Diputados se compondrá de 349 Diputados a Cortes, elegidos directamente por otros tantos distritos electorales". "Para este efecto se dividirán las provincias en distritos electorales a razón de un Diputado y un distrito por cada 35.000 almas de población; pero en las provincias donde resultare un sobrante de 17.500 almas a lo menos, se elegirá un Diputado más, aumentándose un distrito" (art. 2).

Es significativa la restricción importante del sufragio al duplicar las exigencias contributivas para ser elector, pues se pasó de 200 a 400 reales anuales, lo que rebajó el censo electoral al 0,81\% de la población. Con esta Ley se desarrollaron ocho procesos electorales desde 1846 hasta 1864 en los que no dejó de evidenciarse la poca conexión existente entre los dictados normativos y la práctica político-electoral, manejada sin escrúpulos desde el Ministerio de la Gobernación, y que alcanzó, a juicio de algunos ${ }^{34}$, su versíón más organizada durante el mandato de Posada Herrera, entre 1858 y 1863.

Un hito en la historia del pensamiento politico, que tendrá consecuencias en la manera de concebir la articulación del sistema electoral y de la forma de gobierno, fue la publicación, en 1855, del libro de Andrés Borrego, De la organización de los partidos en España, considerada como medido de adelantar la educación constitucional de la nación ${ }^{35}$. De acuerdo con sus ideas, el partido

\footnotetext{
31. Sobre las elecciones, véase el estudio de Natividad Araque Hontagas, Las elecciones en el reinado de Isabel II: la Cámara Baja, Congreso de los Diputados, Madrid, 2008.

32. Las intervenciones está recogidas en el Diario de Sesiones de las Cortes $n^{\circ} 219$, de 7 de junio de 1837.

33. De manera más extensa, Manuel Estrada Sánchez, El significado politico de la legislación electoral en la España de Isabel II,...

34. Así, Melchor Fernández Almagro, "Las Cortes del siglo XIX y la práctica electoral", Revista de Estudios Politicos, n ${ }^{\circ}$ 10, 1943, p. 390; en un sentido similar, SÁNCHEZ AGESTA, Historia del constitucionalismo español,..., pp. 152 y 153

35. Imprenta de Anselmo Santa Coloma, Madrid, 1855; editado también en el CEPC, 2007, con estudio introductorio de Concepción De Castro.
} 
serviría para dar consistencia al sistema de mayoría, cohesionando los votos de la mayoría ministerial y de la oposición minoritaria ${ }^{36}$.

De esa misma época es la Constitución no promulgada de 1856 , que en su artículo 92 configuraba como parte integrante de la norma constitucional, "considerándose para sur reforma y todos sus efectos como artículos constitucionales, las bases de las leyes orgánicas siguientes: $1^{\text {a }}$ La ley electoral"37.

La Ley de 22 de junio de 186438 estableció el procedimiento y la sanción penal para los delitos electorales, con dos previsiones importantes: la consideración como "funcionario público" de cualquiera que en el proceso electoral desempeñara algún cargo, aunque fuera temporal y no retribuido, y la acción penal en estos delitos como popular ${ }^{39}$.

La Ley de 18 de julio $1865^{40}$ adquirió importantes dimensiones cuantitativas (116 artículos) e introdujo algunas novedades significativas: el control judicial de las listas del censo, su formación y rectificación anual, una regulación muy detallada de la votación y la posibilidad de realizar elecciones parciales. El sufragio siguió siendo censitario y capacitario, eligiéndose un diputado en las circunscripciones provinciales por cada 45.000 habitantes.

Con esta Ley se redujo de nuevo la exigencia de renta anual a la prevista en 1837 y que había sido duplicada en 1846; el cambio se debió a una transformación en las costumbres politicas que permitió al Legislador "entregar la investidura de electores a un mayor número de ciudadanos" ${ }^{41}$. Esta Ley se aplicó únicamente a dos elecciones.

A pesar de la apariencia de control que podría suponer cierta judicialización del proceso, no dejó de constatarse su inoperancia pues, como señaló Santamaría de Paredes, servía de poco "la garantía judicial para sumar los resultados de las actas de sección si vienen ya falseadas por las mesas que han presidido las autoridades administrativas" 42 .

36. Ignacio Fernández Sarasola estudia con detalle la relevancia de esta obra de Borrego y su originalidad en el contexto del pensamiento de la época; lo hace en el libro Los partidos politicos en el pensamiento español..., pp. 100 ss. De Andrés Borrego es también la obra Las elecciones, Imprenta de J. Noguera, Madrid, 1875.

37. Véase sobre ese texto no promulgado, la edición de Isabel Casanova Aguilar, Las Constituciones no promulgadas de 1856 y 1873, volumen VI de la Colección Las Constituciones españolas, Iustel, 2008.

38. Gaceta de Madrid, de 23 de junio de 1864.

39. Sobre la evolución de los delitos electorales, véase Esteban Mestre, Los delitos electorales en España (1812-1936), Editora Nacional, Madrid, 1976.

40. Gaceta de Madrid, de 31 de julio de 1865.

41. Manual de legislación electoral y de imprenta: recopilación novísima de las leyes y dispositivos que arreglan en España el ejercicio de los derechos políticos, Madrid, 1865, citado por Pablo Sánchez León, "La pesadilla mesocrática: ciudadanías y clases medias en el orden liberal histórico español", en De súbditos a ciudadanos...", pp. 148 y 159.

42. Curso de Derecho Político, Editorial Ricardo Fe, Madrid, 1898, p. 270; véase, con más detalle, el estudio de Artemi Rallo Lombarte, Garantías electorales y Constitución, CEC, Madrid, 1997, pp. 44 y 45. 


\subsection{La revolución del sufragio universal masculino $y$ sus vaivenes posteriores: 1868-1931.}

Como ya había ocurrido en la década de los treinta del siglo XIX y ocurrirá en la misma década del XX, en 1868 se produjo una "revolución" normativa electoral a través de un decreto: el de 9 de noviembre ${ }^{43}$, que estableció el sufragio universal ${ }^{44}$. Esta norma incluyó las previsiones propias de una ley electoral, habló ya de "elecciones municipales" e incluyó un capítulo específico para los delitos electorales bajo la rúbrica "de la sanción penal". La edad electoral siguió estando fijada en 25 años; se mantuvo la proporción de un diputado por 45.000 habitantes y el sufragio empezó a aproximarse al propio de un sistema democrático: universal masculino, igual, directo y secreto.

Con la introducción del sufragio universal se dio un paso adelante en el proceso de consecución de una ciudadanía igualitaria que inserta a España "en la ola democratizadora europea" 45 , pero, como ya habian ocurrido antes y sucederá más adelante, con evidente retraso: en Francia el Decreto de 5 de marzo de 1848 había introducido el sufragio universal masculino para los mayores de 21 años, universalidad que también aprobó en ese año para los mayores de 25 años la Asamblea Nacional alemana, aunque no se llevó a la práctica hasta mucho después, y que se incorporó a la Constitución de Suiza de 1848 y a la de Dinamarca de 1849.

Las primeras elecciones en las que se aplicó el sufragio universal fueron las municipales de 18 de diciembre de 1868 y, poco después, las elecciones a Cortes Constituyentes del 15 al 17 de enero de $1869^{46}$.

E1 Decreto de 6 de enero de $1869^{47}$ introdujo "varias aclaraciones relativas al ejercicio del sufragio universal" para poner fin a las vacilaciones e incertidumbres suscitadas con la primera aplicación del Decreto de 1868. Es digno de mención que, por vez primera, se incluyan previsiones sobre la forma y el lugar en el que deben votar los electores en servicio activo en el Ejército de Tierra (en el punto en el que se encontraran si hubieran residido durante los últimos dos meses en pueblos de la misma circunscripción) y en la Armada (en el puerto donde se encontrasen si hubieran residido los últimos dos meses en departamentos marítimos de la Península).

La Constitución de $1869^{48}$ es de una extraordinaria parquedad en materia electoral si bien se preocupó de garantizar que "ningún español que se halle en el pleno goce de sus derechos civiles podrá ser privado del derecho de votar en las

43. Gaceta de Madrid, de 10 de noviembre de 1868.

44. Sobre los precedentes de esta medidas y los debates filosófico-políticos, véase Florencia Peyrou, "Demócratas y republicanos: la movilización por la ciudadanía universal", en De súbditos a ciudadanos...", pp. 193 ss.

45. Teresa Carnero Amat, "Ciudadanía politica y democratización. Un paso adelante, dos pasos atrás", en De súbditos a ciudadanos..., p. 226.

46. Sobre estas elecciones y las que se celebraron los siguientes 60 años, véase el estudio de Miguel Martinez Cuadrado, Elecciones y partidos politicos de España (1868-1931), Taurus, Madrid, 1969, vol. I, pp. 59 ss.

47. Gaceta de Madrid, de 7 de enero de 1869.

48. Véase la edición de La Constitución de 1869 a cargo de Manuel Pérez Ledesma, volumen V de la colección Las Constituciones españolas, Iustel, Madrid, 2010. 
elecciones de Senadores, Diputados a Cortes, Diputados provinciales y Concejales" (art. 16), previsión criticada por los sectores conservadores temerosos del otorgamiento al pueblo.

La Norma Fundamental dispuso que "el Congreso se renovará totalmente cada tres años. El Senado se renovará por cuartas partes cada tres años" (art. 39) y que "los Senadores y Diputados representarán a toda la Nación, y no exclusivamente a los electores que los nombraren". No prosperó la reducción de la edad electoral a 20 años propuesta por el diputado José María Orense ${ }^{49}$.

Esta concisión constitucional resultó desarrollada de manera harto extensa con la Ley de 20 de agosto de $1870^{50}$, que alcanzó la cifra de 186 artículos, con previsiones comunes a todos los procesos electorales y otras específicas de cada uno, concluyendo con una detallada regulación de las infracciones electorales dirigida, junto con las cédulas de identificación personal, a fomentar la transparencia.

En general esa Ley no se apartó mucho del decreto de 1868 pero introdujo algunas previsiones importantes, como la de que las elecciones para Diputados a Cortes serian por distritos unipersonales. Cada provincia se dividia en tantos distritos electorales cuantos fueran los Diputados a elegir según su población; habria un distrito por cada 40.000 personas. Además, para democratizar también el sufragio pasivo, se dispuso que diputados y senadores recibirian una retribución fijada legalmente.

Esta normativa, que regirá la celebración de cinco elecciones ${ }^{51}$, resultó completada por la Ley de 11 de enero de 1871 "disponiendo que se plantee la adjunta división de distritos para las elecciones de Diputados a Cortes", cuya distribución se mantendrá, con algunas modificaciones, hasta 1931; por la Ley de 11 de marzo de $1873^{52}$, que rebajó la edad electoral a 21 años, y por el Real Decreto sobre la confección del censo electoral, de 1 de octubre de $1875^{53}$.

La Constitución de $1876^{54}$ es todavía más parca que su predecesora y, sobre todo, menos democrática, pues nada dice del carácter universal del sufragio, remitiéndose (art. 28) al método que determine la ley, aunque Cánovas hubiera preferido excluir ya esa opción, pues para él "el sufragio universal será siempre una farsa, un engaño a las muchedumbres, llevado a cabo por la malicia o la violencia de los menos, de los privilegiados de la herencia y el capital, con el nombre de clases directoras, o será, en estado libre, y obrando con plena independencia y conciencia, comunismo fatal e irresistible..."55. Ya en el artículo

49. Diario de Sesiones de las Cortes, Apéndice 8 al n 29, de 17 de marzo de 1869.

50. Gaceta de Madrid, de 21 de agosto de 1870.

51. Sobre las elecciones generales de 1871, abril y agosto de 1872, 1873 y 1876, véase el trabajo, ya citado, de Martínez Cuadrado, vol. I, pp. 91 ss.

52. Gaceta de Madrid, de 30 de marzo de 1873.

53. Gaceta de Madrid, de 3 de octubre de 1875.

54. Véase la edición de Joaquín Varela Suanzes La Constitución de 1876, volumen VII de la colección Las Constituciones españolas, Iustel, Madrid, 2009.

55. Discurso en el Ateneo de Madrid en 1871; tomo la cita de Luis Díez Del Corral, El liberalismo doctrinario..., p. 577; en su discurso de 15 de marzo de 1876 sostuvo que "el comunismo y el sufragio universal son dos tesis que se resuelven y no pueden menos en resolverse en una sola sintesis"; Discursos parlamentarios, Centro de Estudios Constitucionales, Madrid, 1987, p. 229. 
2 de la Convocatoria para elecciones de 31 de diciembre de 1875, firmada por Cánovas, se decía que "las elecciones de Senadores y Diputados se verificarán, por esta vez, en la propia forma, y con arreglo a las disposiciones bajo las cuales se verificaron las de las mismas Cortes convocadas en 28 de Junio de 1872"56.

La Constitución incluyó una Cámara Alta de 360 miembros compuesta por senadores por derecho propio, vitalicios nombrados por la Corona y senadores elegidos por las corporaciones del Estado y los mayores contribuyentes, y una Cámara Baja integrada por un diputados por cada 50.000 habitantes en los términos que estableciera la ley.

La Ley de 8 de febrero de $1877^{57}$ reguló de manera específica "la elección y composición del Senado", incluyendo entre los legitimados para la elección a corporaciones como los arzobispos, obispos y cabildos eclesiásticos, las Reales Academias, las Universidades y las Sociedades Económicas de Amigos del País. Por su parte, la Ley de 20 de julio de ese mismo año58 restableció, "con carácter provisional la Ley electoral de 18 de Julio de 1865, con las modificaciones que se determinan, para que rijan en las elecciones generales de Diputados a Cortes, si llegaran a verificarse antes de la formación y promulgación de otra nueva".

De lo que se trataba era de retornar al sufragio censitario, lo que se consiguió con la Ley de 28 de diciembre de 187859: "tendrá derecho a ser inscrito como elector en las listas del Censo electoral de la sección de su respectivo domicilio todo español de edad de 25 años cumplidos que sea contribuyente dentro o fuera del mismo distrito, por la cuota mínima para el Tesoro de 25 pesetas anuales por contribución territorial o de 50 por subsidio industrial. Para adquirir el derecho electoral ha de pagarse la contribución territorial con un año de antelación, y el subsidio industrial con dos años" (art. 15) ${ }^{60}$.

La proporción de diputados por habitantes era de uno por cada 50.000 y el desempeño de las funciones representativas volvió a ser gratuito, lo que dificultó que pudieran ser candidatos personas con escasos recursos. Desaparecieron también el requisito de mostrar la credencial para votar y la tipificación de los procedimientos fraudulentos ${ }^{61}$. Se articuló un sistema de voto limitado en las elecciones a Diputados.

56. Véase el Real Decreto de la Presidencia del Consejo de Ministros disponiendo que las Cortes de la Monarquía española se reúnan el 15 de febrero, y señalando los dias en que han de comenzar las elecciones de Senadores y Diputados, disponible en la parte documental del volumen I de esta colección.

57. Gaceta de Madrid, de 10 de febrero de 1877 .

58. Gaceta de Madrid, de 5 de agosto de 1877.

59. Gaceta de Madrid, de 30 de diciembre de 1878.

60. Véanse los estudios de Arturo Fernández Dominguez, Restablecimiento provisional del sufragio censitario: Leyes electorales de 1877 y 1878 de Diputados a las Cortes españolas, Universidad de Málaga, 1985, y Carlos Dardé, “Avanzar retrocediendo. La reforma electoral española de 1878", en Carlos Malamud (coord.), Legitimidad, representación y alternancia en España y América latina: Las reformas electorales (1880-1930), FCE, México, 2000, pp. 19 ss.

61. Para un conocimiento exhaustivo de los procesos electorales regidos por esta Ley, véase el estudio de Martínez Cuadrado, vol. I, pp. 233 ss. 
A pesar del respiro que supuso el periodo 1868-1873, en los años siguientes el panorama electoral siguió siendo tan obscuro y fraudulento como en las dos décadas anteriores, como denunció con bochorno Gumersindo de Azcárate:

\begin{abstract}
"los individuos, unas veces por ignorancia, otras por mala voluntad, apelan a todos los medios para alcanzar la victoria en las campañas electorales, desde el uso de recursos tan groseros como las comilonas y francachelas, o tan criminales como el cohecho o el soborno, hasta el empleo de aquellos otros que sirven de aguijón al interés, al egoísmo, a la vanidad o al amor propio, todos se utilizan sin escrúpulo por los candidatos y sus agentes y todos se aprovechan sin remordimiento por los electores... si hemos de dar crédito a los datos reunidos hace cuatro años por los representantes de Inglaterra en el Continente por encargo de su gobierno, resulta que los dos países en que la inmoralidad de electores y candidatos es mayor son Hungria y España, y los dos en los que el poder ejecutivo interviene más de un modo ilegal y abusivo en las elecciones son Portugal y España. iQué honor para nuestra patria el figurar a la cabeza de ambos aspectos!"62.
\end{abstract}

A pesar de todo, y coincidiendo con la "ola democratizadora" que surcó Europa en los últimos veinte años del siglo XIX ${ }^{63}$, el sufragio universal se recuperó en España con la Ley de 26 de junio de $1890^{64}$. No se recuperaron, sin embargo, ni la exigencia de credencial de elector ni la represión legal del fraude electoral. Además, la capacidad de proponer el nombramiento de interventores que supervisaran los procesos electorales quedaba en manos de los partidos de turno, limitándose en gran medida las posibilidades de control de las formaciones políticas opositoras ${ }^{65}$.

En ese contexto, el retorno al sufragio universal fue más el resultado del cálculo político que de las convicciones democráticas: Sagasta lo aceptó para mantener unido al partido liberal y evitar una escisión de los sectores más progresistas, y desde la derecha se asumió con la tranquilidad de que la Monarquía no perdería sus prerrogativas y la constatación de que podía ser manipulado desde el Ministerio de la Gobernación ${ }^{66}$.

Esta Ley mantuvo en vigor el sistema de distritos electorales aprobado en 1871. La vuelta al sufragio universal implicó que el censo electoral pasara de 56.

62. El régimen parlamentario en la práctica, $3^{\mathrm{a}}$ edición (1 ${ }^{\mathrm{a}}$ en 1885), Tecnos, Madrid, 1978, p.

63. Véanse los estudio de S. P. Huntington, La tercera ola. La democratización a finales del siglo XX, Paidós, Barcelona, 1994, y Manuel Pérez Ledesma, "La conquista de la ciudadanía politica: el continente europeo", en la obra colectiva por él compilada Ciudadanía y democracia, Editorial Pablo Iglesias, Madrid, 2000, pp. 135 ss.

64. Gaceta de Madrid, de 29 de junio de 1890; sobre esta Ley, Carlos Dardé, "Significado politico e ideológico de la ley de sufragio universal de 1890", Anales de la Universidad de Alicante. Historia contemporánea, núm. 10-11, 1993-1994, pp. 67 ss.

65. Véase el trabajo de Artemi Rallo Lombarte, "Origen y evolución de la administración electoral española (1890-1931)", Estudios de derecho público en homenaje a Juan José Ruiz-Rico, Tecnos, Madrid, 1997, pp. 1648 ss.

66. Manuel Pérez Ledesma, "La conquista de la ciudadanía politica...", ob. cit., p. 144; sobre el proceder de Sagasta y la vida política de la época, Carlos Dardé, "La democracia en la España de la Restauración", Revista de Occidente, $\mathrm{n}^{\circ}$ 50, 1985, pp. 115 ss., y, del mismo autor, La aceptación del adversario. Política y politicos de la Restauración, 1875-1900, Biblioteca Nueva, Madrid, 2003. 
unas 800.000 personas a unas 4.800 .000 varones mayores de 25 años ${ }^{67}$. En 1897 se "adaptó" por Real Decreto de 25 de noviembre para las elecciones en las islas de Cuba y Puerto Rico68.

Por su parte, la Ley 8 de agosto de $1907^{69}$ configuró, también por vez primera, el voto como un derecho y un deber, con sanciones para el supuesto de incumplimiento. El artículo 85 exigía la presentación del certificado de haber votado en las últimas elecciones para la toma de posesión de un cargo público.

Esa Ley incorporó otro de los instrumentos que favorecieron los fraudes: la posibilidad de elección sin votación; el artículo 29 disponía que "en los distritos donde no resultaren proclamados candidatos en mayor número de los llamados a ser elegidos, la proclamación de candidatos equivale a su elección y les releva de la necesidad de someterse a ella...". También contribuirá a las componendas entre partidos y la manipulación electoral, la previsión contenida en el artículo 24, que limitaba la posibilidad de ser candidato a quienes ya hubieran desempeñado esa función o fueran avalados por un determinado número de cargos representativos o de electores.

Además, se mantuvo el ejercicio del voto sin necesidad de acreditar la identidad del elector y sin proteger el carácter secreto del sufragio por la inexistencia de sobre electoral, y la función interventora se continuó depositando en los partidos gobernantes ${ }^{70}$. Tampoco se alteró en lo esencial el sistema de distritos uninominales de 1871, que era la base en que se apoyaban los partidos dinásticos y a la que se imputó enorme responsabilidad como factor propicio a la corrupción electoral. En palabras de Adolfo Posada, la Ley era inoperante, no en sí misma, sino por "la fuerza de costumbres electorales de una corrupción que abruma y avergüenza, y ante la falta casi absoluta de espíritu de justicia y de moralidad de los políticos de todos los partidos, que hace que España sea en este punto la nación de politica electoral más degradada y escandalosamente impura de Europa"71. Con esta Ley se celebraron 7 elecciones a Diputados, desde 1910 a $1923^{72}$.

\subsection{La plena democratización del sufragio: 1931-1936.}

La historia constitucional y política española empezó a cambiar a partir del Real Decreto de 13 de marzo de 1931 "disponiendo que las elecciones generales

67. Sobre la composición social y profesional del censo, así como sobre las elecciones en las que se aplicó la Ley de 1890, Martínez Cuadrado, vol. II, pp. 525 ss.

68. Gaceta de Madrid, de 26 de noviembre de 1897.

69. Gaceta de Madrid, de 10 de agosto de 1907.

70. Véase, con más detalle, el trabajo, ya citado, de Teresa Carnero Amat, "Ciudadanía politica y democratización...", pp. 240 ss.

71. "El servicio administrativo de la función de sufragio en la Administración”, Revista Internacional, 5, 1897, p. 254.

72. Sobre dichas elecciones véase el análisis de Martínez Cuadrado, ob. cit., vol. II, pp. 755 ss; sobre la normativa electoral en este periodo el estudio de Mercedes Cabrera y Miguel Martorell, "El Parlamento en el orden constitucional de la Restauración”, en el libro dirigido por Mercedes Cabrera, Con luz y taquigrafos. El Parlamento en la Restauración (1913-1923), Taurus, Madrid, 1998, pp. 56 ss. 
de Ayuntamientos se celebren para la renovación total de sus componentes el día 12 de abril próximo"73.

El Decreto de 25 de abril de $1931^{74}$ reconoció en su Exposición de Motivos "el gran número de errores que el Censo electoral contiene" y pretendió ofrecer "garantía plena de que no se falsea en su formación la voluntad popular". Para ello hizo depender su formación del Ministerio de Trabajo, creó unos organismos administrativos de garantía -los Tribunales del Censo Electoral- y articuló un sistema rápido para la rectificación.

Y, como ya se ha apuntado, otro decreto, el de 8 de mayo de $1931^{75}$, servirá como eficaz ariete normativo "revolucionario" contra las distorsiones a la democracia consagradas en la Ley de 1907. Ese decreto redujo la edad electoral activa y pasiva a los 23 años, permitió la elección de las mujeres, suspendió la aplicación del artículo 29 y estableció que, como regla, la circunscripción sería la provincia, eligiéndose un diputado por cada 50.000 habitantes.

Sendos Decretos, de $3^{76}$ y 5 de junio ${ }^{77}$ de 1931 , dispusieron que "las Cortes Constituyentes, compuestas de una sola Cámara, elegida por sufragio popular directo, se reúnan, para la organización de la República, en el Palacio del Congreso, el día 14 de julio" y que "las elecciones a Cortes Constituyentes se verificarán por el Censo electoral rectificado, y señalando el número de circunscripciones y Diputados que por cada una de ellas habrán de elegirse".

La transformación democrática se consumó con la Constitución de $1931^{78}$ al disponer su artículo 36 que "los ciudadanos de uno y otro sexo, mayores de veintitrés años, tendrán los mismos derechos electorales conforme determinen las leyes", prever en el artículo 52 que "el Congreso de los Diputados se compone de los representantes elegidos por sufragio universal, igual, directo y secreto", y al incorporar fórmulas de democracia directa como las previstas en el artículo 66: "El pueblo podrá atraer a su decisión mediante referéndum las leyes votadas por las Cortes. Bastará, para ello, que lo solicite el 15 por 100 del Cuerpo electoral. No serán objeto de este recurso la Constitución, las leyes complementarias de la

73. Gaceta de Madrid, de 16 de marzo de 1931.

74. Gaceta de Madrid, de 29 de abril de 1931.

75. Gaceta de Madrid, de 10 de mayo de 1931; sobre esta norma, véase el estudio de la época de Francisco López de Goigoechea y Pedro Martínez Cayuela, Ley electoral para diputados a Cortes y concejales: anotada, completada y adaptado a ella el decreto del gobierno provisional de la República de 8 de mayo de 1931 para las elecciones de Cortes Constituyentes, Gráficas Reunidas, Madrid, 1931.

76. Gaceta de Madrid, de 4 de junio de 1931.

77. Gaceta de Madrid, de 7 de junio de 1931.

78. Sobre esta Norma Fundamental y su proceso de gestación véanse los comentarios de la época de Nicolás Pérez Serrano, La Constitución Española (9 de diciembre de 1931). Antecedentes. Texto. Comentarios, Editorial Revista de Derecho Privado, Madrid, 1932; Adolfo Posada, La nouvelle constitution espagnole, Librairie du Recueil Sirey, París, 1932 -hay edición del INAP, 2006, con traducción al castellano y estudio introductorio de Joaquín Varela-, y Antonio Royo Villanova, La Constitución Española de 9 de diciembre de 1931, con glosas jurídicas y apostillas politicas, Imprenta Castellana, Valladolid, 1934; entre los más recientes, Joan Oliver Araujo, El sistema politico de la Constitución española de 1931, Universitat de les Illes Balears, Palma de Mallorca, 1991 y la edición de Santos Juliá, La Constitución de 1931, volumen VIII de la colección Las Constituciones españolas, Iustel, Madrid, 2009. 
misma, las de ratificación de Convenios internacionales inscritos en la Sociedad de las Naciones, los Estatutos regionales, ni las leyes tributarias. El pueblo podrá asimismo, ejerciendo el derecho de iniciativa, presentar a las Cortes una proposición de ley, siempre que lo pida, por lo menos, el 15 por 100 de los electores. Una ley especial regulará el procedimiento y las garantías del referéndum y de la iniciativa popular".

La Constitución (arts. 68 y 121.d) también insertó al Tribunal de Garantías Constitucionales como órgano de control en el nombramiento de los compromisarios que, junto con las Cortes, elegian al Presidente de la República. Estos preceptos fueron desarrollados por la Ley que reguló el procedimiento de elección de compromisarios para los efectos del artículo 68 de la Constitución, de 1 de julio de $19322^{79}$.

La Ley de 27 de julio de $1933^{80}$ introdujo varias modificaciones en el Decreto de 8 de mayo de 1931 en orden a la elección de Diputados a Cortes y Concejales, manteniendo en vigor la Ley de 1907. Destaca la existencia de una doble vuelta que acentúa el carácter mayoritario y que favorecerá las alianzas electorales y el bipartidismo ${ }^{81}$.

\section{PREDOMINIO DE LOS SISTEMAS ELECTORALES MAYORITARIOS EN LA HISTORIA CONSTITUCIONAL ESPAÑOLA.}

En la historia electoral española ha habido una abrumadora presencia de regímenes electorales mayoritarios con el objetivo de consolidar la presencia parlamentaria de la opción política que gozase del favor del electorado, asegurando así, al menos en teoría, la existencia de gobiernos con fuerte respaldo en las Cámaras. Como es obvio, la teoría pasa a un segundo plano cuando, como ocurrió con frecuencia en la segunda mitad del siglo XIX y en los primeros años del XX, los resultados electorales dependian más de las componendas políticas y el fraude sistemático que del riguroso funcionamiento del sistema electoral. En palabras de Joaquín Costa: "no es el régimen parlamentario la regla, y excepción de ella los vicios y las corruptelas denunciadas en la prensa y en el Parlamento mismo durante sesenta años: al revés, eso que llamamos desviaciones y corruptelas constituyen el régimen, son la regla misma"82. En las líneas siguientes haremos una breve descripción de las normas electorales vigentes en España hasta la transición de la dictadura franquista a la democracia constitucional de 1978.

Durante la vigencia del voto indirecto, entre 1810 y 1834 , se combinaron las fórmulas de mayoria simple de votos y mayoría absoluta, si bien no siempre que

79. Gaceta de Madrid, de 3 de julio de 1932; sobre esta cuestión, véase Artemi Rallo Lombarte, "El Tribunal de Garantías Constitucionales como Tribunal de Garantias Electorales", Revista de Estudios Politicos, nº 92, 1996, pp. 251 ss.

80. Gaceta de Madrid, de 28 de julio de 1933.

81. Sobre las distintas propuestas de modificación, véase el estudio de Francesc de Carreras, "Intentos de reforma electoral durante la II República", Revista de Estudios Politicos, n 31-32, 1983, pp. 165 ss.

82. Oligarquía y caciquismo como la forma actual de gobierno en España: urgencia y modo de cambiarla; disponible en

http://www.cervantesvirtual.com/servlet/SirveObras/12405085388048940221802/index.htm 
se hablaba de mayoría absoluta se aludía a la fórmula consistente en obtener la mitad más uno de los votos emitidos. En los casos de empate entre candidatos con el mismo número de votos se acudía al sorteo. La circunscripción era la provincia. En la regulación de 1810 no se aludió al número total de diputados y la proporción era de uno por cada 50.000 personas; en 1820 se menciona la elección de 149 diputados, con una ratio de uno por cada 70.000; en 1834 se elegian 188 diputados.

En las normas de 1836 y 1837 la proporción era de un diputado por cada 50.000 personas para la elección de 258 diputados con un sistema de mayoría a dos vueltas.

Las disposiciones de 1846 y 1865 se caracterizaron por introducir la figura del distrito electoral, con una proporción en la primera de 1 diputado por 35.000 y en la segunda de 1 por 45.000; la fórmula es de mayoría absoluta y, de no conseguirse, la mayoría simple entre los más votados. Con la Ley de 1846 se elegian 349 diputados.

El Decreto de 1868 volvió al sistema de circunscripciones provinciales, aunque en el seno de las mayores podría haber varias divisiones. Se habló por vez primera de mayoría relativa para aludir a la elección del candidato más votado. Pero las normas posteriores de 1870, 1871 y 1877 retornaron al sistema de distritos con mayoria a dos vueltas.

En todo caso, y a partir sobre todo de la Constitución de 1876 y de su aceptación por los dos principales partidos, los textos legales quedaron sometidos a las exigencias del turno, que presuponía la victoria electoral automática del partido que consiguiera la disolución parlamentaria y la convocatoria de elecciones. La contrapartida era la vuelta en el próximo proceso del derrotado en el anterior y la asunción por el vencedor de las acciones legislativas y políticas del que debia abandonar el gobierno.

Las leyes de 1878 y 1890 siguieron con el sistema de distritos aunque en algunos casos eran plurinominales y la novedad más importante para un sistema mayoritario fue la introducción del voto limitado, que en teoría es un instrumento para garantizar una presencia parlamentaria mínima de las fuerzas políticas de la oposición, pero que en España sirvió más para propiciar acuerdos entre los partidos mayoritarios que para favorecer la presencia de las candidaturas minoritarias. Y dichos acuerdos eran posibles por la existencia, como ha señalado Fernández Sarasola, de unos principios comunes que permitían politicas distintas pero no extremas, de manera que, como si se tratara de un sistema de equilibrio constitucional, el Partido Liberal adoptaba el papel de Cámara Baja (impulso) y el Conservador el de Cámara Alta (reflexión y templanza).

El sistema mayoritario incorporó con la Ley de 1907 un nuevo instrumento propicio para la corrupción: la votación sin elección; el artículo 29 disponía que "en los distritos donde no resultaren proclamados candidatos en mayor número de los llamados a ser elegidos, la proclamación de candidatos equivale a su elección y les releva de la necesidad de someterse a ella..." Con este precepto, los partidos mayoritarios contaron con un instrumento adecuado para pactar las personas que debian ser elegidas sin necesidad de afrontar mayores gastos ni incómodas campañas electorales. Precisamente este instrumento fue uno de los derogados por el Decreto de 1931, que mantuvo el voto limitado con el nombre de "restringido" y volvió al sistema de circunscripciones provinciales. 
Esta norma y la Ley de 1933 introdujeron la exigencia de que para resultar elegido no bastaba en primera vuelta tener el mayor número de votos, sino que además debían suponer un porcentaje mínimo de los emitidos (el 20\% en 1931, el $40 \%$ en 1933); de no darse ambas circunstancias era precisa una segunda vuelta el domingo siguiente. Lo que se pretendia era evitar un fraccionamiento excesivo de la Cámara y favorecer el agrupamiento en grandes formaciones pero en la práctica lo que produjo fueron uniones o coaliciones puramente coyunturales que primero polarizaron las elecciones pero luego dieron muestras de fragmentación y fragilidad en sede parlamentaria, lo que ocurrió primero con la CEDA y luego con el Frente Popular ${ }^{83}$. Y es que se trataba ya de la coalición no entre tendencias disgregadas de una misma formación, como habia ocurrido durante la Restauración, sino de auténticos partidos con ideología y organización propias y autónomas, lo que dificultó su cohesión parlamentaria ${ }^{84}$.

\section{III.- EL SISTEMA ELECTORAL A PARTIR DE LA TRANSICIÓN Y DE LA CONSTITUCIÓN DE 1978.}

\subsection{El derecho electoral de la Transición.}

Tendrán que pasar varias décadas de dictadura antes del advenimiento de las siguientes normas electorales, que resurgieron con la Ley 1/1977, de 4 de enero, para la Reforma Politica 85 , donde se dispuso que "los Diputados del Congreso serán elegidos por sufragio universal, directo y secreto de los españoles mayores de edad" (art. 2.2) y que "los Senadores serán elegidos en representación de las Entidades territoriales. El Rey podrá designar por cada legislatura Senadores en número no superior a la quinta parte del de los elegidos" (art. 2.3) ${ }^{86}$.

El decreto, aunque esta vez bajo la forma de decreto-ley, reapareció en la etapa de la Transición para regular las primeras elecciones después de la dictadura; se trató del Decreto-Ley 20/1977, de 18 de marzo, sobre Normas Electorales ${ }^{87}$. A este Decreto-Ley se remitió el Real Decreto 679/1977, de 15 de abril 88 , por el que se convocaron elecciones generales a las Cortes Españoles, que se celebrarian el 15 de junio de 1977, dando lugar a las que luego fueron Cortes constituyentes.

Con la Ley 39/1978, de 17 de julio, de elecciones locales ${ }^{89}$ se llevó a cabo una regulación exhaustiva de los procesos electorales locales, configurándose los municipales e insulares como una elección directa y los provinciales como un

83. Véase al respecto el análisis de Francesc de Carreras y Josep M. Vallés, ob. cit., pp. 238 ss.

84. Véase, con más detalle, Ignacio Fernández Sarasola, Los partidos políticos en el pensamiento español,..., pp. 268 ss.

85. BOE núm. 4, de 5 de enero de 1977.

86. Entre los primeros análisis teóricos del sistema electoral publicados en 1977 cabe mencionar, además del ya citado de Vallés y de Carreras, los de Vallés y Bosch, Las elecciones, Blume, Barcelona, 1977, y De Esteban y otros, El proceso electoral, Labor, Barcelona, 1977.

87. BOE núm. 70, de 23 de marzo de 1977.

88. BOE núm. 92, de 18 de abril de 1977.

89. BOE núm. 173, de 21 de julio de 1978. 
sistema indirecto. Varias de estas previsiones se mantuvieron en esencia en la LOREG.

El precepto que más repercusión tuvo de esa Ley fue el artículo 11.7 ("Tratándose de listas que representen a Partidos Políticos, Federaciones o Coaliciones de Partidos, si alguno de los candidatos electos dejare de pertenecer al partido que le presentó, cesará en su cargo y la vacante será atribuida en la forma establecida en el número anterior. El que así accediere ocupará el puesto por el tiempo que restare de mandato"), finalmente declarado inconstitucional en la medida en que colocaba a la entera disposición del partido político la creación del supuesto de hecho que daba lugar a la pérdida del cargo ${ }^{90}$.

Un último Decreto-Ley permitió que en el referéndum constitucional de 1978 pudieran participar los mayores de 18 años: el Real Decreto-Ley 33/1978, de 16 de noviembre, sobre mayoría de edad"1, dispuso que "la mayoría de edad empieza para todos los españoles a los 18 años cumplidos" (art 1) y ello, como se destaca en la Exposición de Motivos, porque "los supuestos sociales expuestos, unidos al momento de transformación política que vive nuestro país, aconsejan proceder con urgencia a adelantar la mayoría de edad con el objeto de posibilitar la plena incorporación de la juventud española a la vida jurídica, política y social del país".

\subsection{La opción por un sistema electoral supuestamente proporcional.}

La transición de la dictadura a la democracia se articuló a partir de un sistema electoral que, en esencia, sigue vigente cuarenta años después. Ya la Ley para la Reforma Política estableció que la elección de 350 diputados al Congreso se llevaría a cabo de acuerdo con "criterios de representación territorial", pero con la significativa prevención de "dispositivos correctores para evitar fragmentaciones inconvenientes de la Cámara, a cuyo efecto se fijarán porcentajes mínimos de sufragios para acceder al Congreso" (Disposición Transitoria Primera) ${ }^{92}$.

90. Dicho precepto, según el Alto Tribunal, en cuanto otorgaba a los partidos politicos la posibilidad de crear por su voluntad -mediante la expulsión- el presupuesto de hecho que daba lugar al cese en el cargo público, era contrario a la Constitución y, en concreto, al derecho a permanecer en el cargo público de su artículo 23.2 (STC 5/1983, F. 4). Esa era la consecuencia lógica de la configuración del derecho reconocido en el artículo 23.2 como un derecho cuya titularidad exclusiva corresponde a los representantes, y no a las formaciones politicas en cuyas listas electorales han sido elegidos (SSTC 36/1990, F. 1; 30/1993, F. 6; 185/1993, F. 5; 81/1994, F. 2, entre otras muchas); sobre esta jurisprudencia, véase Francisco José Bastida Freijedo, "Derecho de participación a través de representantes y función constitucional de los partidos politicos. (Comentario sobre la idea de representación politica en la jurisprudencia del Tribunal Constitucional)", Revista Española de Derecho Constitucional, n ${ }^{\circ}$ 21, 1987, pp. 200 ss.; Ricardo L. Chueca Rodriguez, "La irreductible dificultad de la representación politica", Revista Española de Derecho Constitucional, no 21, 1987, pp. 186 ss.; y Francisco Caamaño Dominguez, El mandato parlamentario, Congreso de los Diputados, Madrid, 1991, pp. 70 ss. Nos hemos ocupado de estas cuestiones en Los partidos y las distorsiones juridicas de la democracia, Ariel, Barcelona, 2000, y "La sustitución temporal de los representantes políticos", en el libro del mismo título publicado con Carlos Ortega Santiago, CEPC, Madrid, 2009, pp. 15 ss.

91. BOE núm. 275, de 17 de noviembre de 1978.

92. Véase, sobre la Ley para la Reforma Politica y su influencia en nuestro vigente sistema electoral, Alfonso Fernández Miranda, "Los sistemas electorales para el Congreso de los Diputados y el Senado", en IV Jornadas de Derecho Parlamentario. Reflexiones sobre el régimen electoral, 
No menos gráfica es la Exposición de Motivos del citado Decreto-Ley sobre normas electorales donde se afirma -las cursivas son nuestras- que

\begin{abstract}
"determinado por la Ley para la Reforma Política el número total de Diputados y Senadores, corresponde al presente Real Decreto-Ley la distribución de dicho número entre las diferentes provincias españolas. En cuanto a los primeros se ha considerado conveniente asegurar un mínimo inicial de dos Diputados por provincia y dividir el resto de los Diputados en función de la población... De esta forma se suavizan en alguna medida los efectos de nuestra irregular demografia y se atiende a un mayor equilibrio territorial en la representación...

El sistema electoral para el Congreso se inspira en criterios de representación proporcional con candidaturas completas, bloqueadas y cerradas, cuya presentación se reserva a los partidos y federaciones constitutivos de acuerdo con las normas reguladoras del derecho de asociación política, a las coaliciones de estas fuerzas que pueden formarse por mera declaración ante la Junta Electoral Central, y a los propios electores que deseen promover candidaturas determinadas y no de partido.

La distribución de escaños se realizará de acuerdo con la regla de "D'Hondt" que resume en una sola operación el funcionamiento del cociente electoral y el cómputo de restos de acuerdo con el sistema de la mayor media. Esta misma regla ya supone un poderoso corrector del excesivo fraccionamiento de las representaciones parlamentarias. A esta misma finalidad, responde la exclusión en la atribución de escaños de aquellas listas de candidatos que no hubieran obtenido, al menos, el $3 \%$ de los votos emitidos en la circunscripción".
\end{abstract}

En estas lineas aparecen las claves de bóveda de nuestro vigente sistema electoral, tanto estatal como autonómico: a) el mapa, con un mínimo de diputados por circunscripción" ${ }^{93}$; b) una distribución de escaños que "suaviza en alguna medida los efectos de nuestra irregular demografia y atiende a un mayor equilibrio territorial en la representación"; c) las candidaturas de listas cerradas y bloqueadas; d) la fórmula electoral "D'Hondt"; e) la barrera electoral y f) la voluntad decidida de corregir el "excesivo fraccionamiento de las representaciones parlamentarias".

Así pues, ya en este Real Decreto-Ley se establecieron las criterios para que el régimen electoral generara un sistema en el que no todos los partidos politicos tendrian una presencia parlamentaria proporcional a su aceptación entre el electorado, donde las formaciones politicas partieran en una situación de ventaja respecto a las meras agrupaciones temporales de ciudadanos y en el cual la determinación del orden de colocación en las listas electorales dependiera de los órganos de dirección de los partidos; se pretendía, en suma, fortalecer a los partidos politicos en general y a los que obtuvieran respaldo electoral mayoritario en particular ${ }^{94}$.

Madrid, Congreso de los Diputados, pp. 521 ss.; y Ángel Sánchez Navarro, Constitución, igualdad y proporcionalidad electoral, Madrid, Centro de Estudios Políticos y Constitucionales, Madrid, 1998, pp. 66 y ss.

93. Manuel Martínez Sospedra remonta el origen del mínimo inicial de dos diputados a la regulación que hizo la Ley Orgánica del Estado, en 1966, al cambiar la redacción primitiva del artículo 2 de la Ley de Cortes; véase su estudio sobre "El régimen electoral Valenciano" en Cuadernos de Derecho Público, 22-23 (Monográfico sobre el régimen electoral de las Comunidades Autónomas), 2004, p. 411.

94. Para un análisis actualizado de esta cuestión véase el estudio de Roberto Blanco Valdés, "La caída de los dioses: de los problemas de los partidos a los partidos como problema", Teoría y Realidad Constitucional, $\mathrm{n}^{\circ}$ 35, 2015, pp. 149 ss. 
En lo que al sistema de partidos se refiere, y como explican Lago y Montero ${ }^{95}$, lo que se buscaba, y se consiguió, fue "diseñar un sistema electoral que permitiera al partido en el Gobierno (UCD) alcanzar a la vez dos objetivos. El primero consistía en lograr que las fuerzas políticas a su derecha y a su izquierda apoyaran la combinación de los elementos del sistema electoral. El segundo radicaba en maximizar su representación parlamentaria de acuerdo con la información que poseían durante esa fase de la transición democrática. Al cumplirse el primer objetivo, el sistema electoral español comenzó su larga andadura institucional. Y al realizarse el segundo objetivo, la combinación de los efectos mayoritarios y conservadores se proyectó de modo diferenciado sobre los principales partidos de centro-derecha (como la propia UCD) o de centroizquierda".

Estas previsiones normativas estuvieron muy presentes en el proceso de elaboración del texto constitucional y con su incorporación a la Norma Fundamental ${ }^{96}$ se convirtieron en algo indisponible para las Cortes Generales ${ }^{97}$, formando, en expresión gráfica, nuestra "Constitución electoral"98, con su ejemplo más acabado en el artículo 68, que fija el número máximo y mínimo de diputados, el carácter del sufragio, la circunscripción provincial, la proporcionalidad de la representación, la duración del mandato, quiénes son electores y elegibles, y la franja temporal de celebración de las elecciones ${ }^{99}$.

95. Ob. cit., p. 283.

96. Con la objeción del Partido Comunista por la merma de proporcionalidad que suponían; al respecto son muy ilustrativas las palabras del Diputado Solé Tura el 12 de julio de 1978 en la Sesión Plenaria del Congreso de los Diputados que debatía el Dictamen de la Comisión de Asuntos Constitucionales y Libertades Públicas sobre el Anteproyecto de Constitución, Diario de Sesiones del Congreso de los Diputados, $\mathrm{n}^{\circ}$ 108, pp. 4184 ss. Puede consultarse en http://www.congreso.esy en Constitución española. Trabajos parlamentarios, Madrid, Cortes Generales, 1980, Tomo II, pp. 2236 ss.; véanse también las consideraciones incluidas en el estudio de Jordi Solé Tura y Miguel Ángel Aparicio Pérez, Las Cortes Generales en el sistema constitucional, Tecnos, Madrid, 1984; me ocupé de esta cuestión en "Crónica de una desproporcionalidad anunciada", en Estudios sobre la Constitución Española: homenaje al profesor Jordi Solé Tura, Congreso de los Diputados, 2008, Vol. 1, pp. 859-874.

97. Una postura crítica con la incorporación a la Norma Fundamental de numeras prescripciones electorales es la de Enrique Arnaldo Alcubilla, El carácter dinámico del régimen electoral español, Madrid, CEPC, pp. 11 ss.

98. Francisco Caamaño Domínguez, “Elecciones y Tribunal Constitucional. ¿Una intersección no deseada?”, Revista de las Cortes Generales, n 41, p. 95.

99. "1. El Congreso se compone de un mínimo de 300 y un máximo de 400 Diputados, elegidos por sufragio universal, libre, igual, directo y secreto, en los términos que establezca la ley. 2. La circunscripción electoral es la provincia. Las poblaciones de Ceuta y Melilla estarán representadas cada una de ellas por un Diputado. La ley distribuirá el número total de Diputados, asignando una representación mínima inicial a cada circunscripción y distribuyendo los demás en proporción a la población. 3. La elección se verificará en cada circunscripción atendiendo a criterios de representación proporcional. 4. El Congreso es elegido por cuatro años. El mandato de los Diputados termina cuatro años después de su elección o el día de la disolución de la Cámara. 5. Son electores y elegibles todos los españoles que estén en pleno uso de sus derechos políticos. La ley reconocerá y el Estado facilitará el ejercicio del derecho de sufragio a los españoles que se encuentren fuera del territorio de España. 6. Las elecciones tendrán lugar entre los treinta días y sesenta días desde la terminación del mandato. El Congreso electo deberá ser convocado dentro de los veinticinco dias siguientes a la celebración de las elecciones". 
Aquí están los elementos del sistema electoral para el Congreso de los Diputados, cuya articulación procedimental se deja en manos del Legislador ${ }^{100,}$ que cuando se decidió a desarrollarlo admitió sin pudor que su renovación no era en modo alguno radical, "debido a que el propio texto constitucional acogió los elementos esenciales del sistema electoral contenidos en el Real Decreto-Ley" (Exposición de motivos de la Ley Orgánica del Régimen Electoral General, LOREG).

Y, como complemento de lo anterior y evidencia de la conexión entre partidos y régimen electoral, la Ley 54/1978, de 4 de diciembre, de partidos políticos, ya contempló el éxito electoral como una clave para la supervivencia económica de las formaciones políticas: según el artículo 6,

"la Administración del Estado financiará las actividades de los partidos con arreglo a las siguientes normas: Cada Partido percibirá anualmente una cantidad fija por cada escaño obtenido en cada una de las dos cámaras y, asimismo, una cantidad fija por cada uno de los votos obtenidos por cada candidatura a cada una de las dos cámaras. En los Presupuestos Generales del Estado se consignará la cantidad global destinada a estos fines, así como los criterios para distribuirla con sujeción a lo dispuesto en el apartado anterior. Reglamentariamente se determinará el régimen de distribución de las cantidades mencionadas en el apartado a cuando los Partidos hubieran concurrido a las elecciones formando parte de federaciones o coaliciones".

\subsection{Un sistema electoral de listas cerradas y bloqueadas para el Congreso y de lista abierta para el Senado.}

Como ya se ha dicho, el Decreto-Ley de 18 de marzo de 1977 apostó, para el Congreso de los Diputados, por "candidaturas completas, bloqueadas y cerradas, cuya presentación se reserva a los partidos y federaciones constituidos de acuerdo con las normas reguladoras del derecho de asociación política, a las coaliciones de estas fuerzas que pueden formarse por mera declaración ante la Junta Electoral Central, y a los propios electores que deseen promover candidaturas determinadas y no de partido" y, en consecuencia, se dispuso que "cada uno de los electores de un distrito sólo podrá dar su voto a una sola lista, sin introducir en ella modificación alguna ni alterar en la misma el orden de colocación de los candidatos" (art. 20.3).

En la misma línea, y años después de la entrada en vigor de la Norma Fundamental, la LOREG dispuso (art. 96.4) que "serán también nulos en todos los procesos electorales los votos emitidos en papeletas en las que se hubieren modificado, añadido o tachado nombres de candidatos comprendidos en ellas o alterado su orden de colocación..."

El sistema de listas cerradas y bloqueadas -así se denominan en varias Leyes electorales autonómicas- favorece que quede en manos de los órganos de dirección de la formación que promueve la candidatura la composición y

100. Miguel Azpitarte Sánchez señala que "mientras que el sistema electoral demanda una mayor rigidez constitucional que evite su disponibilidad en manos de mayorias contingentes, se puede afirmar que la menor rigidez del procedimiento electoral facilita su adaptación a los cambios que impulsa y exige la experiencia de cada contienda electoral"; véase su trabajo " $L a$ dimensión constitucional del procedimiento electoral", Teoría y Realidad Constitucional, $\mathrm{n}^{\circ} 11-12$, $\mathrm{p}$. 443. 
ordenación de la misma, a salvo de lo que puedan disponer los respectivos estatutos internos en materia de elecciones primarias, lo que, hasta la fecha, ha favorecido una férrea disciplina de partido. $Y$ ello a pesar del mandato constitucional (art. 6) que impone una estructura interna y un funcionamiento democráticos ${ }^{101}$, cuyo desarrollo legislativo se realizó en los preceptos no derogados de la Ley 21/1976, de 14 de junio, de Asociaciones Politicas; en la ya citada Ley 54/1978, de 4 de diciembre, de Partidos Políticos, aprobada antes que el propio texto constitucional, pero teniendo en cuenta los inmediatos dictados de este último, y, finalmente, en la Ley Orgánica 6/2002, de 27 de junio, de partidos políticos, reformada por la Ley Orgánica 3/2015, de 30 de marzo, que modifica, entre otros, aunque sin cambios trascendentales, los artículos 7 (sobre la organización y funcionamiento) y 8 (derechos y deberes de los afiliados) ${ }^{102}$.

Creo que, en esencia, siguen siendo válidas, veintitrés años y algunas reformas legales después, las palabras empleadas por el Tribunal Constitucional en 1995 para calificar la normativa entonces vigente: "el Legislador ha optado por establecer unas muy parcas reglas de organización y funcionamiento democráticos y por reconocer unos muy escuetos derechos de los afiliados" (STC 56/1995, de 6 de marzo, F. 3.b). En esta resolución, el TC precisa, por vez primera de modo expreso, el contenido del último párrafo del artículo 6, conectándolo con el cumplimiento de las funciones públicas por parte de las formaciones políticas: "el mandato constitucional conforme al cual la organización y funcionamiento de los partidos politicos debe responder a los principios democráticos constituye, en primer lugar, una carga impuesta a los propios partidos con la que se pretende asegurar el efectivo cumplimiento de las funciones que éstos tienen constitucional y legalmente encomendadas y, en último término, contribuir a garantizar el funcionamiento democrático del Estado" (F. 3.1.a).

Un ámbito en el que una de las facetas de la democracia interna, entendida como participación de los militantes en las decisiones más relevantes del partido, es clave para contribuir al funcionamiento democrático del Estado es, precisamente, el de la formación de las candidaturas que esa entidad presentará para los órganos que ejercen funciones de representación politica. Sin embargo, ni la normativa reguladora del régimen electoral ni la propia del sistema de partidos han querido propiciar instrumentos que hagan efectiva la exigencia constitucional.

101. Véanse, al respecto, los estudios de Fernando Flores Giménez, La democracia interna de los partidos politicos, Congreso de los Diputados, Madrid, 1998, y José Ignacio Navarro Méndez, Partidos politicos y democracia interna, CEPC, Madrid, 1999; más recientes los de Eduardo Vírgala Foruria, "Ejercicio de derechos por los afiliados y control judicial de las sanciones impuestas por los partidos políticos", Teoría y Realidad Constitucional, n 6, 2000, pp. 83 ss.; "Democracia interna y derechos de los afiliados a los partidos politicos", Revista Catalana de Dret Públic, $\mathrm{n}^{\circ}$ 37, 2008, pp. 21 ss., y "La regulación juridica de la democracia interna en los partidos politicos y sus problemas en España", Teoria y Realidad Constitucional, n 35, 2015, pp. 225 ss.

102. Puede verse una amplia panorámica doctrinal sobre la legislación de partidos en España en el número monográfico de Teoría y Realidad Constitucional, $\mathrm{n}^{\circ}$ 35, 2015; pueden resultar de especial interés dos de las últimas encuestas de esa misma revista: la que se incluye en el número 31, de 2013, sobre el control del poder, con participación de los profesores Blanco Valdés, Chueca, Corcuera, Presno y Rodríguez Diaz (pp. 15 ss.), y la que ofrece expresamente sobre los partidos en ese número 35, de 2015, con participación de los profesores Aragón, Bastida, Bilbao, Cámara, Contreras, Carmona, Elvira, Morales, Porras Nadales y Torres Muro (pp. 15 ss.). 
Y el Legislador no puede dejar en manos exclusivas de las formaciones políticas la decisión de si sus candidaturas electorales se aprobarán, o no, con la participación de los afiliados. La especial posición que la Constitución ha otorgado a los partidos es la que justifica que, entre otras ventajas, reciban cuantiosas ayudas públicas, económicas o no, pero al tiempo es la que demanda un cierto intervencionismo estatal en la vida interna del partido para asegurar que en los actos con trascendencia constitucional externa -la presentación de candidaturas lo es $^{103}$ - se respete la expresa exigencia constitucional de funcionamiento interno democrático. En palabras de Kelsen, la inserción constitucional de los partidos políticos hace también -debe hacer añadimos nosotros- posible la democratización de la formación de la voluntad colectiva dentro de esa esfera ${ }^{104}$.

No se trata de que la Ley imponga un concreto modelo de democracia interna entre los diferentes posibles, sino de que obligue, so pena de no aceptar las candidaturas, a que su formación responda a un mínimo democrático ${ }^{105}$.

Esta pretensión optimista -por utilizar la expresión de Pérez-Moneo ${ }^{106}$ - de intervencionismo estatal en aspectos de la vida interna de los partidos ha sido cuestionada históricamente argumentado, entre otros, motivos realistas -decía Michels que si las leyes quieren poner coto al dominio de los dirigentes, poco a poco cederán las leyes, no los dirigentes ${ }^{107}$ - pero también hace ya tiempo que está consolidada en realidades legislativas como la norteamericana ${ }^{108}$. En todo caso, y volviendo a Kelsen, la intervención del Estado en la vida del partido tiene como finalidad superar una realidad que, por lo general, "sólo brinda al individuo... un mínimo de autodeterminación democrática"109.

Y, en lo que al régimen electoral español respecta, esa intervención ya se viene produciendo, por citar algún ejemplo, en la imposición a las candidaturas de un sistema de inelegibilidades, que podría ampliarse, y a través de la exigencia de una composición equilibrada entre hombres y mujeres, avalada esta última por el Tribunal Constitucional en la STC 12/2008, de 29 de enero.

La exigencia legal de la elección democrática de los integrantes de las candidaturas no plantearía, a nuestro juicio, problemas de constitucionalidad;

103. Véase, al respecto, su detallado estudio La selección de candidatos electorales en los partidos, CEPC, Madrid, 2012; en especial, las páginas 163 ss.

104. De la esencia y valor de la democracia, edición de Juan Luis Requejo Pagés, KRK, Oviedo, 2006, p. 85.

105. Fernando Flores Giménez expone los argumentos a favor de una legislación más intensa sobre los partidos, "Los partidos politicos: intervención legal y espacio politico, a la búsqueda del equilibrio", Teoria y Realidad Constitucional, n $35, \ldots$, pp. 362 ss.

106. La selección de candidatos electorales en los partidos, CEPC, Madrid, 2012, pp. 111 ss.

107. En "Democracia formal y realidad oligárquica", K. Lenk y F. Neumann (eds.), Teoría y sociología críticas de los partidos politicos, Anagrama, 1980, p. 257.

108. En su estudio clásico sobre la Constitución y los partidos políticos, Heinrich Triepel se ocupó, ya en 1927, del sistema norteamericano de primarias como una muestra de la penetración democrática por vía legislativa en el sistema de partidos para que éste pueda convertirse en piedra angular de la organización del Estado; La Constitución y los partidos politicos, Tecnos, 2015 pp. 26 ss.

109. Ob. cit., pp. 85 y 86. 
tampoco el desbloqueo de las listas. Como razona el Tribunal en la STC 12/2008, es evidente que la libertad de presentación de candidaturas por los partidos (que, por lo demás, en ésta como en sus demás actividades están sometidos a la Constitución y a la ley, como expresa el art. $6 \mathrm{CE}$ ) no es, ni puede ser, absoluta. Ya el Legislador, en atención a otros valores y bienes constitucionales protegidos, ha limitado esa libertad imponiéndoles determinadas condiciones para la confección de las candidaturas (referidas a la elegibilidad de los candidatos, a la residencia en algunos supuestos, o incluso a que tales candidaturas hayan de serlo mediante listas cerradas y bloqueadas).

Por ello, nuevas limitaciones orientadas a hacer realidad la democracia interna en las formaciones políticas y a favorecer las opciones de la ciudadanía que participa en los procesos electorales ni son las únicas ni carecen de fundamento constitucional: en primer lugar porque son constitucionalmente legitimos fines como la consecución de la democracia interna en el seno de las formaciones políticas o favorecer la amplitud de opciones en el proceso electoral; en segundo lugar, porque no se trataría de imponer un concreto mecanismo de elección interna (primarias abiertas, cerradas,...), sino de permitir que cada formación pudiese optar por una fórmula que, en todo caso, asegurase esa participación efectiva ${ }^{110}$; en fin, porque es inocuo para los derechos fundamentales de quienes, siendo sus destinatarios, los partidos politicos, no son, por definición, titulares de los derechos fundamentales de sufragio activo y pasivo.

En esa línea, el reformado artículo 7 de la Ley Orgánica 6/2002 ya prevé que la estructura interna y el funcionamiento de los partidos politicos deberán ser democráticos, estableciendo, en todo caso, fórmulas de participación directa de los afiliados en los términos que recojan sus Estatutos, especialmente en los procesos de elección de órgano superior de gobierno del partido. A esta cláusula se podría añadir y "elección de los integrantes de las candidaturas que, en su caso, se presenten a los diferentes procesos electorales". Estas previsiones, de manera similar a lo que ocurre en Alemania ${ }^{111}$, tendrian que tener su correlato en la LOREG y en los estatutos de cada formación política; de esa manera se respetaría su libertad de autoorganización y el propio derecho de sus afiliados a tomar parte en esa decisión, contando para ello con los oportunos recursos internos y, especialmente, administrativo-electorales y judiciales que permitan verificar la corrección democrática del proceso ${ }^{112}$.

110. Véase, al respecto, los trabajos de David Giménez Gluck, "El derecho de asociación de los partidos politicos y la regulación legal de las elecciones primarias", Revista Española de Derecho Constitucional, $\mathrm{n}^{\circ}$ 102, pp. 211 ss., y Eduardo Virgala Foruria, "La regulación jurídica de la democracia interna en los partidos políticos y sus problemas en España", Teoría y Realidad Constitucional,.., pp. 236 ss., que incluye un exhaustivo análisis de los procesos de primarias en España y, en general, de las exigencias de funcionamiento democrático que cabria imponer legalmente a los partidos.

111. Una completa exposición de la legislación alemana en lengua española es la de Yolanda Fernández Vivas en "El régimen de los partidos politicos en Alemania", Teoría y Realidad Constitucional, $\mathrm{n}^{\circ} 31$, pp. 457 ss. Una panorámica con perspectiva histórica dentro de la doctrina alemana es la que se ofrece en el libro colectivo coordinado por Dimitris Tsatsos 30 Jahre Parteiengesetz in Deutschland, Nomos, Baden-Baden, 2002.

112. Entre los estudios más completos de la doctrina española en esta materia cabe recordar, además de los ya citados, la ponencia presentada en el XII Congreso de la Asociación de Constitucionalistas de España (Salamanca, 2014) por Emilio Pajares Montolío, "Selección de 
En ese proceso interno de elección de los integrantes de las candidaturas tendria que operar el principio de voto libre y secreto de los afiliados y el derecho de cualquiera de las personas afiliadas a ser candidata, ambas cosas previstas ya en la normativa vigente para la elección de los órganos directivos. En dichos comicios, como regla, operaría la de la mayoría simple; esta exigencia se ha incluido en el nuevo artículo 3.2 de la Ley Orgánica 6/2002, a propósito de los órganos de gobierno y representación -los Estatutos deberán incluir "las reglas de deliberación y la mayoría requerida para la adopción de acuerdos, que, por regla general, será la mayoría simple de los presentes, sean éstos miembros de pleno derecho o compromisarios"-. Así, las disposiciones estatutarias podrían exigir mayorias cualificadas para la toma de decisiones como la presente si las consideran de especial relevancia para la vida del partido y a propósito de las cuales se busca un respaldo superior al de la mera mayoría simple. Nada impediría tampoco que la formación política abriera el proceso de elección a personas no afiliadas, bien para el sufragio activo, para el pasivo o para ambos.

Por lo que respecta al desbloqueo de las listas, tal reforma daría más libertad al votante, fomentaria la conexión entre electores y elegidos y liberaría algo más a los electos respecto a sus formaciones políticas. No obstante, tendría que compatibilizarse, en la LOREG, con el sistema de elección interna al que acabamos de referirnos y con la obligación de una composición equilibrada entre mujeres y hombres de las listas. A estos efectos, se mantendría la selección de candidatos realizada previamente en el seno de la formación que promueve la candidatura pues seguiria siendo una lista cerrada y, por tanto, no cabría incluir a personas ajenas a la misma; en segundo lugar, y teniendo en cuenta el especial valor político que se suele atribuir a la cabecera de la lista se podría prever que el desbloqueo no afectase a la persona que ocupa el primer lugar en la candidatura, posición que, además, tiene relevancia jurídica en las elecciones locales, dado que para optar a la Alcaldía la LOREG exige (art. 196.a) haber encabezado la correspondiente lista ${ }^{113}$.

También, y afectos de no hacer especialmente complejo ni el voto ni el escrutinio en circunscripciones grandes, cabria optar por un desbloqueo parcial, limitándolo, como mucho, a los puestos 2 al 10. Otra cautela sería prever que el desbloqueo se condicionaría a la obtención de un mínimo de votos a favor por parte del electorado. Finalmente, y en aras a mantener la exigencia actual de composición equilibrada de mujeres y hombres, el desbloqueo tendria que realizarse en los dos primeros tramos de cinco puestos (del 2 al 5 y del 6 al 10).

candidatos y mejora del sistema electoral: consideraciones sobre las elecciones primarias", en Participación, representación y democracia: XII Congreso de la Asociación de Constitucionalistas de España, coordinado por José Luis Cascajo Castro y Augusto Martín de la Vega, Tirant lo Blanch, Valencia, 2015, pp. 151-192; también el trabajo de Paloma Biglino Campos, "Intervención del Legislador y selección de candidatos por los partidos políticos: una perspectiva comparada", Teoría y Realidad Constitucional, $\mathrm{n}^{\circ} 35, \ldots$, pp. 203 ss.; Octavio Salazar Benitez y Alejandro Saiz Arnáiz se ocuparon de los primeros procesos: "Las primarias socialistas: una experiencia de democratización de la selección de candidatos", Teoría y Realidad Constitucional, n ${ }^{\circ}$ 6, pp. 135 ss.; "Elecciones primarias, representación política y democracia interna en los partidos: entre la ilusión y el escepticismo" Anuario de Derecho Constitucional y Parlamentario, n ${ }^{\circ} 12-13$, pp. 179 ss.

113. Según la STC 31/1993, de 26 de enero, esta condición de cabeza de lista ha de conectarse a una determinada lista de candidatos en un determinado proceso electoral abierto, lista a la que se refiere el art. 44. 1 LOREG, que sólo puede ser presentada por partidos y federaciones, coaliciones de partidos o agrupaciones de electores (F. 3). 
Finalmente, por lo que respecta al Senado, es sabido que en las elecciones a la Cámara Alta opera un sistema peculiar de lista abierta, no previsto para otro tipo de procesos electorales: "En cada provincia se elegirán cuatro Senadores por sufragio universal, libre, igual, directo y secreto por los votantes de cada una de ellas, en los términos que señale una ley orgánica. En las provincias insulares, cada isla o agrupación de ellas, con Cabildo o Consejo Insular, constituirá una circunscripción a efectos de elección de Senadores, correspondiendo tres a cada una de las islas mayores -Gran Canaria, Mallorca y Tenerife- y uno a cada una de las siguientes islas o agrupaciones: Ibiza-Formentera, Menorca, Fuerteventura, Gomera, Hierro, Lanzarote y La Palma. Las poblaciones de Ceuta y Melilla elegirán cada una de ellas dos Senadores" (art. 69.2, 3 y 4).

En desarrollo de esta previsión constitucional, el artículo 166 de la Ley Orgánica del Régimen Electoral General dispone que "la elección directa de los Senadores en las circunscripciones provinciales, insulares y en Ceuta y Melilla se rige por lo dispuesto en los apartados siguientes: a) Los electores pueden dar su voto a un máximo de tres candidatos en las circunscripciones provinciales, dos en Gran Canaria, Mallorca, Tenerife, Ceuta y Melilla, y uno en las restantes circunscripciones insulares. b) Serán proclamados electos aquellos candidatos que obtengan mayor número de votos hasta complementar el de Senadores asignados a la circunscripción".

Nos encontramos, pues, ante un sistema de lista abierta -el votante puede seleccionar tres nombres de diferente color político-, voto limitado -hay que escoger menos personas de las que se eligen en la circunscripción- y fórmula electoral mayoritaria -resultan elegidas las cuatro personas más votadas en la circunscripción-. Esa libertad que ofrece la lista abierta no es, en la inmensa mayoría de los casos, aprovechada por el votante, que actúa de acuerdo con criterios de política general y no atendiendo a la personalidad de los candidatos, algo no exento de lógica pues no parece sencillo que candidatos que defienden diferentes propuestas electorales puedan ponerse de acuerdo luego para unificar sus lineas de actuación política.

Por ello, lo habitual es que los resultados del Senado coincidan, maximizándolos, con los resultados del Congreso: al elegirse a pocos senadores en cada provincia y a través de una fórmula electoral mayoritaria, quien gana las elecciones al Congreso suele tener un resultado todavia mejor en el Senado y cuando nos encontramos con mayorias diferentes en una y otra Cámara ello se debe al vuelco que pueden provocar en la composición del Senado los 58 senadores propuestos por los Parlamentos autonómicos.

Sea como fuere, la composición del Senado refleja más una representatividad politica general, como el Congreso, que una de carácter territorial y ésta última solo tiene sentido si plantea como algo diferente de la representación general y unitaria del pueblo del Estado.

\subsection{Un sistema electoral proporcional que produce resultados desiguales.}

Si hay otro factor, y bien conocido, que ha venido incidiendo de manera muy relevante en la minoración del pluralismo representativo en el Congreso de los Diputados es el juego combinado de la fórmula electoral, el número de escaños a elegir por circunscripción y el tamaño de las entidades representativas: una cámara parlamentaria de 350 miembros -Montero y Riera hablan aquí de la "ley 
de la raíz cúbica"114_ junto con un tamaño reducido de las circunscripciones provocará que, aunque se emplee una fórmula de carácter proporcional se asistirá a una "distribución desproporcionada de escaños", que beneficiará a los grandes partidos e incrementará la posibilidad de que se den mayorias parlamentarias artificiales de un partido que ha obtenido una victoria electoral minima ${ }^{115}$.

Eso es, precisamente, lo que ha venido ocurriendo en España: en 1982 el Partido Socialista Obrero Español consiguió 202 escaños (57,71\%) con el 48,11\% de los votos; en 1986 esa misma formación política obtuvo 184 escaños (52,57\%) con el 44,06\% de sufragios; en las elecciones del año 2000 fue el Partido Popular el que con el 44,52\% de votos llegó a los 183 escaños $(52,28 \%)$ y en 2011 con el 44,63\% de votos a los 186 (53,14\%); en 1989 el PSOE llegó a 175 diputados $(50 \%)$ con el $39,6 \%$ de votos ${ }^{116}$.

Un régimen electoral que genera estos resultados ha sido, sin embargo, avalado por el Tribunal Constitucional, que, si bien comenzó señalando que "la representación proporcional es la que persigue atribuir a cada partido o a cada grupo de opinión un número de mandato en relación con su fuerza numérica. Cualesquiera que sean sus modalidades concretas, su idea fundamental es la de asegurar a cada partido político o grupo de opinión una representación, si no matemática, cuando menos sensiblemente ajustada a su importancia real" (STC 40/1981, de 18 de diciembre, F. 2), a continuación matizó que "la proporcionalidad en la representación, dificil de alcanzar de suyo, lo es tanto más cuanto menor sea el abanico de posibilidades dado por el número de puestos a cubrir en relación con el de las fuerzas concurrentes... Consecuencia de ello es que la "adecuada representación proporcional" exigida sólo podrá serlo imperfectamente en el margen de una discrecionalidad que la hagan flexible, siempre que no altere su esencia"; será preciso, "en todo caso, evitar la aplicación pura y simple de un criterio mayoritario o de mínima corrección”.

La jurisprudencia posterior ha ido en la línea de otorgar una gran deferencia al Legislador electoral (SSTC STC 75/1985, de 21 de junio; 225/1998, de 25 de noviembre y, más recientemente, 19/2011, de 3 de marzo). La STC 75/1985, que enjuició aspectos del Decreto-Ley de 1977 se limitó a decir que de la aplicación de la formula D'Hondt a nuestras circunscripciones "resulta cierta ventaja relativa aunque no superior a la de otras fórmulas consideradas igualmente

114. Ob. cit., p. 387; actualizando su cálculo (de 2009) para una población, a diciembre de 2017, de 46.549.045 habitantes la raíz cúbica sería 359,72.

115 . Véase al respecto, Arendt Lijphart, Sistemas electorales $y$ sistemas de partidos, Centro de Estudios Constitucionales, Madrid, 1995, pp. 119 ss., y 182 ss. Recuerdan Lago y Montero que, "tras décadas de investigación sobre las consecuencias políticas de los sistemas electorales, uno de los puntos básicos de encuentro es que la fragmentación de un sistema de partidos, la proporcionalidad electoral, los votos malgastados o la sobrerrepresentación de los partidos mayoritarios dependen de la magnitud de distrito (entendida como el número de escaños que se elige en una circunscripción)", ob. cit. p. 321. Me he ocupado de estas cuestiones en El derecho de voto: un derecho politico fundamental, libro electrónico,

http://presnolinera.files.wordpress.com/2011/10/el-derecho-de-voto-un-derechopolc3adticofundamental-libro.pdf, y en El derecho de voto: un derecho político fundamental, Porrúa, México, D. F. 2013.

116. Fuente: Ministerio del Interior (http://www.infoelectoral.interior.es/min/home.html) (25 de enero de 2018). 
proporcionales- para las listas más votadas, y ello como consecuencia del peculiar sistema de cocientes sucesivos que dicha regla articula..."

Por su parte, en la STC 19/2011, que aunque se refiere a la elección de una Cámara autonómica es extrapolable a las elecciones al Congreso, se concluye (F.3) que

\begin{abstract}
"las genéricas directrices constitucionales... a favor de la proporcionalidad determinan la existencia de un considerable ámbito de indefinición en cuanto al tipo de escrutinio, así como en cuanto a la regulación de otros aspectos del proceso electoral; y esta indefinición únicamente puede ser salvada mediante decisiones del legislador, y en la amplia diversidad de soluciones que éste puede adoptar no cabe apreciar sino una confirmación de la naturaleza de las normas, que en otras ocasiones hemos considerado integrantes de un 'bloque de la constitucionalidad' como un espacio abierto a distintas posibilidades legislativas, naturaleza que, en cuanto entraña un bien constitucional en sí mismo valioso, lejos de resultar debilitada, ha de ser preservada y reforzada por este Tribunal". No se trata, en ningún caso, de la exigencia de un sistema puro de proporcionalidad, sino que, por el contrario, la proporcionalidad "es, más bien, una orientación o criterio tendencial, porque siempre, mediante su puesta en práctica, quedará modulada o corregida por múltiples factores del sistema electoral hasta el punto de que puede afirmarse que cualquier concreción o desarrollo normativo del criterio, para hacer viable su aplicación, implica necesariamente un recorte a esa 'pureza' de la proporcionalidad abstractamente considerada" (STC 75/1985, de 21 de junio, FJ 5).

"En tanto el legislador se funde en fines u objetivos legitimos y no cause discriminaciones entre las opciones en presencia, no cabrá aceptar el reproche de inconstitucionalidad de sus normas o de sus aplicaciones en determinados casos, por no seguir unos criterios estrictamente proporcionales (STC193/1989)" (STC 45/1992, de 2 de abril, FJ 4; doctrina que reitera ATC 240/2008, de 22 de julio).
\end{abstract}

El problema es que lo que resulta de la vigente normativa es mucho más que "cierta ventaja relativa" y, desde luego, esa ventaja, a diferencia de lo que sostiene el Tribunal, sí es superior a la de otras fórmulas consideradas igualmente proporcionales. Basta tomar el propio ejemplo práctico que facilita la LOREG en su artículo 163 -y que reproducen luego las leyes electorales autonómicas- y comparar los resultados que ahí se muestran con los que generaría, por ejemplo, la fórmula Sainte-Laguë, que en lugar de dividir entre la sucesión de números naturales desde el 1 hasta el que coincida con el de escaños a elegir en la circunscripción (fórmula D'Hondt) divide entre los números impares.

Ejemplo del artículo 163 LOREG: 480.000 votos válidos emitidos en una circunscripción que elija ocho Diputados. Votación repartida entre seis candidaturas y aplicación de la fórmula D'Hondt (no se incluye la división hasta ocho para ahorrar espacio y porque no es necesaria para mostrar lo que se pretende): 
EL SISTEMA ELECTORAL ESPAÑOL DESDE SUS ORÍGENES ...

\begin{tabular}{|c|c|c|c|c|c|}
\hline ón Divisi & 1 & 2 & 3 & 4 & 5 \\
\hline A & 168.000 & 84.000 & 56.000 & 42.000 & 33.600 \\
\hline B & 104.000 & 52.000 & 34.666 & 26.000 & 20.800 \\
\hline $\mathrm{C}$ & 72.000 & 36.000 & 24.000 & 18.000 & 14.400 \\
\hline D & 64.000 & 32.000 & 21.333 & 16.000 & 12.800 \\
\hline $\mathrm{E}$ & 40.000 & 20.000 & 13.333 & 10.000 & 8.000 \\
\hline $\mathrm{F}$ & 32.000 & 16.000 & 10.666 & 8.000 & 6.400 \\
\hline
\end{tabular}

En negrita el reparto de escaños: la candidatura A obtiene cuatro; la candidatura B, dos escaños y las candidaturas C y D, un escaño cada una.

Con esos mismos parámetros la aplicación de la fórmula Sainte-Laguë genera más proporcionalidad y pluralismo: la candidatura A obtiene tres escaños.; la candidatura B, dos escaños y las candidaturas C, D y E, un escaño cada una.

\begin{tabular}{|c|c|c|c|c|c|c|c|c|}
\hline ón & Divisi & 1 & & 3 & & 5 & & 7 \\
\hline & A & $\begin{array}{ll} & 168.00\end{array}$ & 00 & 56.0 & 00 & 33.6 & 00 & 24.0 \\
\hline & B & $\begin{array}{ll}0 & 104.00\end{array}$ & 66 & 34.6 & 00 & 20.8 & 57 & 14.8 \\
\hline & $\mathrm{C}$ & 72.000 & 00 & 24.0 & 00 & 14.4 & 85 & 10.2 \\
\hline & D & 64.000 & 33 & 21.3 & 00 & 12.8 & 2 & 9.14 \\
\hline & $\mathrm{E}$ & 40.000 & 33 & 13.3 & 0 & 8.00 & 4 & 5.71 \\
\hline & $\mathrm{F}$ & 32.000 & 66 & 10.6 & 0 & 6.40 & 1 & 4.57 \\
\hline
\end{tabular}

Téngase en cuenta que este efecto de desproporcionalidad (la candidatura con más votos resulta sobrerrepresentada en ese ejemplo con un escaño), no casual como ya se ha apuntado, es probable que se produzca en todas las circunscripciones a las que se asignan pocos escaños.

Además de la anterior evidencia, tampoco parece muy acertado concluir, como hace el Tribunal Constitucional, que la proporcionalidad "es, más bien, una 
orientación o criterio tendencial, porque siempre, mediante su puesta en práctica, quedará modulada o corregida por múltiples factores del sistema electoral hasta el punto de que puede afirmarse que cualquier concreción o desarrollo normativo del criterio, para hacer viable su aplicación, implica necesariamente un recorte a esa 'pureza' de la proporcionalidad abstractamente considerada" (STC 75/1985, de 21 de junio, FJ 5). "En tanto el legislador se funde en fines u objetivos legítimos y no cause discriminaciones entre las opciones en presencia, no cabrá aceptar el reproche de inconstitucionalidad de sus normas o de sus aplicaciones en determinados casos, por no seguir unos criterios estrictamente proporcionales (STC193/1989)" (STC 45/1992, de 2 de abril, FJ 4; doctrina que reitera ATC 240/2008, de 22 de julio).

$\mathrm{Y}$ es que, en primer lugar, la proporcionalidad no es un mero "criterio tendencial" sino un mandato constitucional orientado a hacer realidad, como minimo, dos valores superiores del ordenamiento -la igualdad y el pluralismo político-; el mandato del artículo 9.2 -promover las condiciones para que la igualdad del individuo y de los grupos en que se integra sean reales y efectivas...-, el objeto protegido por los derechos fundamentales reconocidos en los artículos 23.1 y 23.3, el carácter igual del sufragio en las elecciones al Congreso garantizado por el artículo 68.1 y que la elección se verifique atendiendo a criterios de representación proporcional (art. 68.3). Lo que cabe colegir de este último precepto, en palabras de Francisco Bastida, es que no es suficiente que en el resultado final haya proporcionalidad si ésta no se produce también en cada circunscripción ${ }^{117}$, cosa que ya hemos visto que no ocurre en la mayoría. Por si fuera poco, como explica también Bastida, esa proporcionalidad tampoco se da porque asi lo quiso el Legislador preconstitucional $y$ lo ha avalado el postconstitucional- en el resultado final de cada renovación del Congreso de los Diputados.

En segundo término, el Legislador sí está causando "discriminaciones entre las opciones en presencia", pues no las trata de la manera más igual posible, sino que se decanta por unos mecanismos (asignar un mínimo de 2 diputados por circunscripción, mantener la elección de 350 diputados y, por tanto, un Congreso de tamaño "pequeño", optar por una fórmula electoral que no es proporcional en circunscripciones pequeñas) que, de antemano, provocan desproporcionalidad y afectan al principio de igual (o similar) valor del voto; como se ha visto más arriba, los dos mecanismos de ventaja, el reparto mayoritario y la sobrerrepresentación, se acumulan sobre los ganadores en ciertos distritos.

Como concluyen Penadés y Santauste, "la competición electoral en España no tiene lugar en condiciones iguales en todas las circunscripciones, y los votos no cuentan todos lo mismo. La variabilidad de la magnitud electoral de los distritos tiene consecuencias para el sistema de partidos. Además, el sistema electoral emplea un método de prorrateo de escaños entre las circunscripciones que introduce otra dimensión de desigualdad: la representación de los ciudadanos"118.

117. "Proporcionalidad inversa en la representación e inconstitucionalidad de la Ley Orgánica del Régimen Electoral General. Propuesta para una reforma", El informe del Consejo de Estado sobre la reforma electoral, ...., p. 707.

118. Ob. cit., p. 90. 
A esta perspectiva, que analiza la vulneración del principio de igualdad del sufragio, Lago y Montero añaden otra: este malapportionment (de origen) es un recurso institucional manejado estratégicamente por las élites partidistas para conseguir mayorias parlamentarias amplias, asegurar su acceso a la formación de gobiernos y facilitar la aprobación de sus politicas ${ }^{119}$.

El propio Consejo de Estado señaló, en su Informe de 2009 (p. 157) , “que el sistema electoral del Congreso de los Diputados,..., presenta algunos aspectos que podrian ser susceptibles de mejora, en aras de garantizar la igualdad de electores y partidos políticos en el proceso electoral y de revalorizar la participación de los ciudadanos en la designación de sus representantes... Un avance en este sentido podría comportar efectos beneficiosos para el fomento de la participación política de los ciudadanos y una mayor implicación de éstos en el funcionamiento democrático de las instituciones, en línea con lo ya dispuesto en la inmensa mayoría de los ordenamientos europeos".

Es obvio que el Legislador español -primero el preconstitucional y luego el postconstitucional- no ha introducido una prima explícita a la mayoria, como si ha sucedido en otros sistemas electorales de nuestro entorno ${ }^{120}$, pero si ha propiciado que exista esa prima encubierta, pues no cabe calificar de otro modo esa continuada diferencia entre votos conseguidos y escaños alcanzados.

Y una situación de desigualdad entre las opciones político-electorales como la que se produce en España sería calificada como inconstitucional en Alemania y así ha ocurrido en varias ocasiones (véase al respecto la BVferGE 121, 266, de 3 de julio de 2008) ${ }^{121}$ : la igualdad de oportunidades de los partidos se irradia sobre el régimen electoral en su conjunto (Chancengleichheit) y, en concreto, sobre la introducción de un determinado sistema, que, a su vez, condiciona la existencia de más o menos grupos parlamentarios ${ }^{122}$.

Pero la tacha de inconstitucionalidad no se ha limitado a la legislación alemana; en el caso italiano, la vigencia de un sistema electoral (la Ley $\mathrm{n}^{\circ}$

119. Ob. cit., p. 327; para Alfonso Fernández Miranda la estabilidad parlamentaria y la gobernabilidad son, precisamente, evidencias de que el régimen electoral no es tan negativo; $o b$. cit., pp. 701 ss.

120. Puede verse una sucinta exposición del premio de mayoría en el panorama electoral europeo en la sentencia del Tribunal Europeo de Derechos Humanos en el caso Saccommano y otros c. Italia, de 13 de marzo de 2012.

121. Véanse los comentarios de H. H. von Arnim, "Verfassungswidrigkeit des Bundeswahlgesetzes aufgrund des "negativen Stimmge-wichts" - Anmerkungen zum Urteil des Bundesverfassungsgerichts vom 3. Juli 2008", en Recht und Politik, n 44, pp. 136-138, y Dieter Nohlen "Erfolgswertgleichheit als fixe Idee oder: Zurück zu Weimar? Zum Urteil des Bundesverfassungsgerichts über das Bundeswahlgesetz vom 3. Juli 2008”, Zeitschrift für Parlamentsfragen, $\mathrm{n}^{\circ} 40$, pp. 179-195; para una perspectiva completa del sistema electoral germano, J. Behnke, Das Wahlsystem der Bundesrepublik Deutschland. Logik, Technik und Praxis der Verhältniswahl, Nomos, Baden-Baden, 2007. Sobre el sistema electoral alemán en la doctrina española y su incidencia en el sistema de partidos, véase el ya citado estudio de Yolanda Fernández Vivas, Igualdad y partidos politicos. Análisis constitucional y comparado de la igualdad de oportunidades de los partidos políticos,..., en particular, pp. 37 ss.; sobre las últimas reformas en la materia, Carlos Vidal Prado, "El sistema electoral alemán como modelo: ventajas $e$ inconvenientes", Asamblea. Revista parlamentaria de la Asamblea de Madrid, n 26, pp. 217 ss.

122. Dieter Nohlen, Wahlrecht und Parteiensystem: Zur Theorie und Empirie der Wahlsysteme, Verlag Barbara Budrich, 2009. 
270/2005) con un ingente premio en escaños a la coalición electoral que obtuviera la mayoría relativa ha implicado, como recuerda Ferrajoli (2011, p. 46), que la coalición vencedora pudiera acreditarse como mayoría absoluta, "sustituyendo en la propaganda la realidad por la ficción jurídica". Tales previsiones, como argumentó el Tribunal Constitucional italiano en la Sentencia $1 / 2014$ al declarar que esa normativa era inconstitucional, alteraban "el circuito democrático" basado en el principio de esencial igualdad del sufragio y producian "un'alterazione profonda della composizione della rappresentanza democratica, sulla quale si fonda l'intera architettura dell'ordinamento costituzionale vigente... ${ }^{123}$

\section{IV.- EPÍlOGO: ¿EL SISTEMA ELECTORAL EN EL FUTURO?}

Parece difícilmente compatible con una "sociedad democrática avanzada", a la que alude el Preámbulo de nuestra Constitución, el mantenimiento de un sistema electoral que declara como objetivos explicitos "suavizar la demografia" y "corregir la representación parlamentaria" pero que, sobre todo, que está pensado para facilitar que determinadas formaciones politicas puedan conseguir mayorias absolutas con porcentajes de votos de poco más del $40 \%$. Es ese régimen el que ha venido provocando que a lo largo de casi cuarenta años, y en las ya citadas palabras de Penadés y Santauste, la competición electoral en España no haya tenido lugar en condiciones iguales en todas las circunscripciones, y que los votos no valgan lo mismo. De esta manera, se han venido ocasionando menoscabos en la expresión de la representatividad, además de las distorsiones generadas en el sistema de partidos. Como concluyen Lago y Montero, estamos ante un recurso institucional manejado estratégicamente por las élites partidistas para conseguir mayorias parlamentarias amplias, asegurar su acceso a la formación de gobiernos y facilitar la aprobación de sus políticas.

No se trata, al menos no aquí, de proponer un sistema electoral alternativo124; sí de insistir en que la proporcionalidad no es un mero "criterio tendencial" sino un mandato constitucional orientado a hacer realidad, como minimo, dos valores superiores del ordenamiento -la igualdad y el pluralismo político-; el mandato del artículo 9.2 -promover las condiciones para que la igualdad del individuo y de los grupos en que se integra sean reales y efectivas...-, el objeto protegido por los derechos fundamentales reconocidos en los artículos 23.1 y 23.3, el carácter igual del sufragio en las elecciones al Congreso garantizado por el artículo 68.1 y que la elección se verifique atendiendo a criterios de representación proporcional (art. 68.3). Y, como se ha visto, ni se consigue la proporcionalidad constitucionalmente querida en la mayoría de las circunscripciones ni tampoco en el resultado final de cada renovación del Congreso de los Diputados.

Las distorsiones maquiavélicas que el actual régimen electoral provoca en la vida politica se evidencian también en todo lo que tiene que ver con su

123. Pueden leerse los numerosos comentarios a esta sentencia en la página http://www.giurcost.org/decisioni/index.html,

124. Sobre una eventual importación del sistema alemán, véase el estudio de Carlos Vidal Prado, El sistema electoral alemán y su posible implantación en España, Tirant lo Blanch, 2012. 
financiación y ello en aras al mantenimiento del statuo quo articulado desde los inicios de la transición de la dictadura a la democracia.

Por otro lado, el Legislador no puede dejar en manos exclusivas de las formaciones políticas la decisión de si sus candidaturas electorales se aprobarán, o no, con la participación de los afiliados. La especial posición que la Norma Fundamental ha otorgado a los partidos es la que demanda un cierto intervencionismo estatal en su vida interna para asegurar que en los actos con trascendencia constitucional externa como la presentación de candidaturas se respete la expresa exigencia constitucional de funcionamiento democrático. Estas previsiones, de manera similar a lo que ocurre en Alemania, tendrian que tener su correlato en la LOREG y en los estatutos de cada formación política; de esa manera se respetaría su libertad organizativa y el propio derecho de sus afiliados a tomar parte en esa decisión

En palabras del Consejo de Estado, "un avance en este sentido podría comportar efectos beneficiosos para el fomento de la participación politica de los ciudadanos y una mayor implicación de éstos en el funcionamiento democrático de las instituciones, en línea con lo ya dispuesto en la inmensa mayoría de los ordenamientos europeos".

Enviado el (Submission Date): 04/02/2018

Aceptado el (Acceptance Date): 12/04/2018 